NBER WORKING PAPER SERIES

\title{
RETURNS TO SKILLS AROUND THE WORLD: EVIDENCE FROM PIAAC
}

\author{
Eric A. Hanushek \\ Guido Schwerdt \\ Simon Wiederhold \\ Ludger Woessmann \\ Working Paper 19762 \\ http://www.nber.org/papers/w19762 \\ NATIONAL BUREAU OF ECONOMIC RESEARCH \\ 1050 Massachusetts Avenue \\ Cambridge, MA 02138 \\ December 2013
}

We would like to thank Andreas Schleicher and William Thorn from the OECD for access to and help with the international PIAAC data, as well as Dan McGrath, Eugene Owen, and Saida Mamedova from the National Center for Education Statistics and the PIAAC team at GESIS for providing access to the U.S. and German continuous-earnings data, respectively. Simon Wiederhold and Ludger Woessmann gratefully acknowledge financial support from the European Union's FP7 through the LLLight'in'Europe project. Simon Wiederhold also gratefully acknowledges the hospitality of the OECD in Paris during the initial phase of work on this paper The views expressed herein are those of the authors and do not necessarily reflect the views of the National Bureau of Economic Research.

NBER working papers are circulated for discussion and comment purposes. They have not been peerreviewed or been subject to the review by the NBER Board of Directors that accompanies official NBER publications.

(C) 2013 by Eric A. Hanushek, Guido Schwerdt, Simon Wiederhold, and Ludger Woessmann. All rights reserved. Short sections of text, not to exceed two paragraphs, may be quoted without explicit permission provided that full credit, including (C) notice, is given to the source. 
Returns to Skills around the World: Evidence from PIAAC

Eric A. Hanushek, Guido Schwerdt, Simon Wiederhold, and Ludger Woessmann

NBER Working Paper No. 19762

December 2013

JEL No. I20,J31

\begin{abstract}
$\underline{\text { ABSTRACT }}$
Existing estimates of the labor-market returns to human capital give a distorted picture of the role of skills across different economies. International comparisons of earnings analyses rely almost exclusively on school attainment measures of human capital, and evidence incorporating direct measures of cognitive skills is mostly restricted to early-career workers in the United States. Analysis of the new PIAAC survey of adult skills over the full lifecycle in 22 countries shows that the focus on early-career earnings leads to underestimating the lifetime returns to skills by about one quarter. On average, a one-standarddeviation increase in numeracy skills is associated with an 18 percent wage increase among prime-age workers. But this masks considerable heterogeneity across countries. Eight countries, including all Nordic countries, have returns between 12 and 15 percent, while six are above 21 percent with the largest return being 28 percent in the United States. Estimates are remarkably robust to different earnings and skill measures, additional controls, and various subgroups. Intriguingly, returns to skills are systematically lower in countries with higher union density, stricter employment protection, and larger public-sector shares.
\end{abstract}

\author{
Eric A. Hanushek \\ Hoover Institution \\ Stanford University \\ Stanford, CA 94305-6010 \\ and NBER \\ hanushek@stanford.edu \\ Guido Schwerdt \\ University of Siegen \\ Hölderlinstr. 3 \\ 57076 Siegen GERMANY \\ guido.schwerdt@vwl.uni-siegen.de
}

\author{
Simon Wiederhold \\ Ifo Institute for Economic Research \\ Poschingerstr. 5 \\ 81679 Munich, Germany \\ wiederhold@ifo.de \\ Ludger Woessmann \\ University of Munich \\ Ifo Institute for Economic Research and CESifo \\ Poschingerstr. 5 \\ 81679 Munich, Germany \\ woessmann@ifo.de
}




\section{Introduction}

The skills of the population are generally viewed as a key ingredient in modern knowledgebased economies (e.g., Hanushek and Woessmann (2008)). However, existing evidence on the returns to skills in the labor market is surprisingly limited, coming almost exclusively from earnings of early-career workers in the United States. As a result, any sense of how rewards to skills evolve over the work life or of how they might differ across economies is absent. ${ }^{1}$ New international data from the Programme for the International Assessment of Adult Competencies (PIAAC) dramatically changes the ability to understand how economies value skills. Using these data, this paper provides new insights into the value of skills in different economic settings by developing estimates of the earnings returns to cognitive skills across the entire labor force for 22 countries.

Unlike the case of the returns to school attainment, obtaining estimates of the value of individual cognitive skills has had to rely on a small number of specialized data sets. While assessments of the achievement of students are common, tested students are seldom followed from school into the labor market where the impact of differential skills can be observed.

Developing estimates of the returns to skill has most generally relied on U.S. panel data that permit observing the subsequent earnings of youth who can be followed into their initial jobs. ${ }^{2}$ However, estimates based on such early-career earnings are likely to suffer from downward lifecycle bias as people with higher lifetime earnings show systematically steeper earnings growth (Haider and Solon (2006)). Furthermore, individual skills may take time to be revealed (Altonji and Pierret (2001)). Importantly, returns to skills may also depend on a country's specific labor-market and social institutions.

The main prior source of international comparisons of returns to cognitive skills has come from analyses of the International Adult Literacy Survey (IALS), collected in the mid-

\footnotetext{
${ }^{1}$ There has been extensive estimation of returns to school attainment as found in Mincer earnings functions with Psacharopoulos and Patrinos (2004) providing estimates for some 98 countries. Nonetheless, these estimates provide limited comparative information that can indicate how different economies value skills (see the discussion in Hanushek and Woessmann (2012)). Note also that, for expositional simplicity, we simply use common but imprecise language interpreting the earnings impact of additional years of schooling as the return to schooling; see Heckman, Lochner, and Todd (2006).

${ }^{2}$ See, for example, Bishop (1989), Murnane, Willett, and Levy (1995), Neal and Johnson (1996), Mulligan (1999), Murnane et al. (2000), Lazear (2003), and Chetty et al. (2011). Bowles, Gintis, and Osborne (2001) provide an early survey of studies of achievement effects, and Hanushek and Woessmann (2008) and Hanushek and Rivkin (2012) survey more recent evidence.
} 
1990s. ${ }^{3}$ However, the returns from two decades ago may no longer be good indicators of the situation in economies that have undergone substantial technological change (Autor, Levy, and Murnane (2003); Goldin and Katz (2008); Acemoglu and Autor (2011)). Moreover, while informative, the IALS analyses suffer from a number of limitations: a restricted number of 15 countries with relevant data, relatively small sample sizes, and skill tests that assess very basic competencies.

The new PIAAC survey, conducted under the auspices of the Organisation for Economic Co-operation and Development (OECD) in 2011-2012 and released in the fall of 2013, provides a number of advantages over existing datasets. First, while again observing people across the entire work life, it covers more countries (currently 22, but ultimately up to 33). Second, it provides substantially larger sample sizes per country (more than twice the effective IALS sample sizes), allowing richer analyses in subgroups. ${ }^{4}$ Third, PIAAC substantially extends the depth and range of measured skills including an attempt to assess problem-solving skills in technology-rich environments.

This paper makes three contributions to the literature. First, we place individual earnings in a more general human capital model and then document the pattern of returns to cognitive skills, focusing on variations in overall earnings impacts across 22 countries. Second, we provide evidence on the sensitivity of these returns to varying samples, measures, and specifications. Third, we describe how these returns differ according to features of country economies including union density and various labor and product market regulations.

Our results confirm that estimates based on early-career earnings underestimate the lifetime returns to skills, in our analyses by an average of about one quarter. Across the 22 countries, a one-standard-deviation increase in numeracy skills is associated with an average 18 percent wage increase among prime-age workers. Moreover, because of measurement errors in skills, these estimates should be thought of as lower bounds on the return to skill.

But this overall measure of returns to skill also masks considerable cross-country heterogeneity: Returns are below 15 percent in eight countries, including all four participating

\footnotetext{
${ }^{3}$ See Leuven, Oosterbeek, and Ophem (2004), Denny, Harmon, and O’Sullivan (2004), Hanushek and Zhang (2009), and Barone and van de Werfhorst (2011) along with the review in Hanushek and Woessmann (2011). Other country-specific uses of the IALS data are found in McIntosh and Vignoles (2001), Green and Riddell (2003), and Green and Riddell (2013) who also use data from the 2003 follow-on Adult Literacy and Life Skills Survey (ALL).

${ }^{4}$ In total, the sample of prime-aged, full-time workers is more than three times as large in PIAAC as in IALS.
} 
Nordic countries, and above 21 percent in six countries, with the largest return being 28 percent in the United States. Estimated returns tend to be largest for numeracy and literacy skills and smaller for problem-solving skills, although the relative importance of different skill dimensions varies across countries. Estimates prove highly robust to different earnings measures, additional controls, and various subgroups. Finally, exploiting the cross-country dimension of our analysis, we find that returns to skills are systematically lower in countries with higher union density, stricter employment protection, and larger public-sector shares.

In the following, Section 2 provides our conceptual framework and derives our empirical model. Section 3 introduces the PIAAC data. Section 4 presents our empirical results on returns to skills in the different countries, going into the details of model specifications, different skill domains, heterogeneous returns, and robustness checks. Section 5 presents stylized facts about what accounts for differences in skill returns across countries. Section 6 concludes.

\section{Conceptual Framework and Empirical Model}

Even though the labor economics literature is replete with analyses of how workers' wages are determined, we believe that it has settled on a stylized model that in the main derives from common measurement and data deficiencies. We begin by broadening the perspective on human capital and wages to include recognition of elements of skill determination. We follow this with details of our empirical approach.

\subsection{Conceptual Framework}

Most analyses of individual earnings rest on a very simple underlying model of human capital, which we can write simply as (Hanushek and Woessmann (2008)):

$$
y=\gamma H+\varepsilon
$$

where individual earnings ( $y$ ) are a function of the labor-market skills, or human capital, of the individual $(H)$. The stochastic term $(\varepsilon)$ represents idiosyncratic earnings differences, generally presumed in empirical analyses to be orthogonal to $H$.

Human capital is nonetheless a latent variable. A central part of the critique of early human capital ideas was that human capital was inherently an elusive concept that lacked any satisfactory measurement. Early arguments, for example, suggested that differences in earnings 
were caused by skill or human capital differences and thus that measurement of human capital could come from observed wage differences - an entirely tautological statement. To be useful and verifiable, it is necessary to specify the measurement of $H$.

The contributions of Jacob Mincer were especially important in establishing the course of empirical work. Mincer $(1970,1974)$ argued that a primary motivation for schooling was developing the general skills of individuals and, therefore, that it made sense to measure human capital by the amount of schooling completed by individuals. From this, Mincer showed how wage differentials could be significantly explained by school attainment and, in a more nuanced form, by on-the-job training investments. This insight was widely accepted and has dictated the empirical approach of a vast majority of empirical analyses in labor economics through today.

It has obviously been productive to rely on this formulation, because information on school attainment is frequently measured and reported in surveys and censuses that also contain earnings information. Propelled by readily available data on school attainment within and across countries, economists have devoted considerable energy to estimating the returns to additional years of schooling in formulations that are based on substituting years of schooling $(S)$ for $H$ in equation (1). This work has been summarized and interpreted in a number of different places. ${ }^{5}$

But Mincer's empirical innovation has perhaps been too successful as it has also led researchers to ignore many important and continuing measurement issues. Implicitly, the standard Mincer formulation assumes that schooling is the sole systematic source of skill differences.

In a different branch of research, a vast amount of research has delved into "educational production functions." This work has considered how, besides schools, also other factors enter into the determination of skills. ${ }^{6}$ This line of research indicates that skills are affected by a range of factors including family inputs $(F)$, the quantity and quality of inputs provided by schools (which we incorporate as the function $Q(S)$, where $S$ is school attainment), individual ability $(A)$, and other relevant factors $(X)$ that include labor-market experience, health, and so forth. Along with a stochastic term $(v)$, assumed uncorrelated with the other determinants of $H$, we can write a linear version of this general model simply as:

\footnotetext{
${ }^{5}$ See early discussions in Mincer (1970) and Griliches (1977) and more recent reviews in Card (1999) and Heckman, Lochner, and Todd (2006). In an international context, see Harmon, Oosterbeek, and Walker (2003) and Psacharopoulos and Patrinos (2004).

${ }^{6}$ See, for example, the general discussion in Hanushek (2002).
} 


$$
H=\lambda F+\phi Q(S)+\delta A+\alpha X+v
$$

Some empirical applications of this production function model have simply substituted equation (2) into equation (1) and directly estimated the impact of various inputs into the educational process on income, presumably arising from their impact on relevant labor-market skills. More commonly, however, estimation is restricted just to equation (2) where skills $(H)$ are measured by achievement tests. This analysis also matches more closely current educational policy debates that are centered on improving levels of student achievement and reducing the variance in such outcomes across schools and population groups.

This work on the determinants of skills implies that it is inappropriate just to substitute a single input into skills (importantly, such as $S$ ) into equation (1) to estimate the impact of human capital on earnings. It is highly unlikely that the stochastic term, $\varepsilon$, is orthogonal to school attainment once it is recognized that it includes the other determinants of skills.

There is a long line of research focused on whether omitting individual ability, $A$, leads to bias in the estimated returns to schooling if more able students tend to attain more schooling. ${ }^{7}$ But the more general issue is that schooling is just one of a series of well-researched factors that affect individual skills. The natural interactions among these various factors and school attainment suggest that the simple estimation of the schooling-earnings relationship is prone to severe biases that are difficult to correct in any satisfactory way.

Our estimation follows an alternative approach built on direct measures of cognitive skills. ${ }^{8}$ Consider test score measures of the relevant human capital skills - that is, standardized assessments of numeracy and literacy achievement. If these measures, denoted $C$, completely captured variations in $H$, the key parameter ( $\gamma$ ) of equation (1) could be directly estimated by using $C$ as the measure of $H$. Further, if school quantity, $S$, were added to the estimation equation, it would have no independent influence (in expectation), because the relevant skills were fully contained in $C$.

\footnotetext{
${ }^{7}$ See Card (1999). Indeed, one approach to looking at the returns to schooling is simply to estimate a standard Mincer earnings function with an additive test score that is alternatively interpreted as ability or as school quality. But neither is consistent with the educational production functions of equation (2). Skill tests are to varying degrees subject to the influences depicted in equation (2), and thus are not generally thought of as fixed ability. Alternatively, as a measure of school quality, such measures should modify the impact, or marginal product, of time spent in formal schooling. See also Hause (1972) on the functional form.

${ }^{8}$ This view is closely related to the empirical analysis in Neal and Johnson (1996) and Murnane et al. (2000).
} 
But few people believe that existing test data are complete measures of $H$. Instead, the achievement test measures, $C$, are best thought of as error-prone measures of $H$ :

$$
C=H+\mu
$$

With classical measurement error, one would expect the estimate of $\gamma$ in equation (1) to be biased toward zero, and, if $S$ and $C$ are positively correlated as would be expected, the coefficient on $S$ in the same estimated equation would be biased upward, even if $S$ had no independent effect over and above its relationship with $C$. This simple model would imply that the coefficient on $C$ would be a lower bound on the impact of human capital on incomes. ${ }^{9}$

The discussion is further complicated by the fact that part of the return to cognitive skills undoubtedly comes through continuation in school. There is substantial U.S. evidence that students who do better in school, either through grades or scores on standardized achievement tests, tend to go farther in school. ${ }^{10}$ Murnane et al. (2000) separate the direct returns to measured skill from the indirect returns of more schooling and suggest that perhaps one-third to one-half of the full return to higher achievement comes from further schooling. Similarly, Rivkin (1995) finds that test score variation captures a considerable proportion of the systematic variation in high-school completion and in college continuation, to the extent that test score differences can fully explain black-white differences in schooling. Indeed, this relationship between cognitive skill and further investments in formal schooling is implicit in the idea of skill complementarities over the life cycle, as development by James Heckman and his co-authors (e.g., Cunha et al. (2006); Cunha and Heckman (2007)) and summarized by the stylized conclusion that "skill begets skill." Early measures of human capital contained in cognitive skills during the schooling process index future additions to human capital, again thought of in terms of the quality of skills.

\subsection{Empirical Model}

Following this conceptualization, our baseline empirical model is simply an analog to a Mincer equation except that it is built on measured cognitive skills $(C)$ instead of years of schooling:

\footnotetext{
${ }^{9}$ Unfortunately, while information on test reliability would help to bound the potential effects of measurement error, we do not have such information for these tests. Note also that the standard test-retest measures of reliability will themselves understate the amount of error in our measure, because we are interested in using the tests to measure the concept of human capital - which is undoubtedly broader than the test constructs that have been developed.

${ }^{10}$ See, for example, the early work by Dugan (1976) and Manski and Wise (1983).
} 


$$
\ln y_{i}=\beta_{0}+\beta_{1} C_{i}+\beta_{2} E_{i}+\beta_{3} E_{i}^{2}+\beta_{4} G_{i}+\varepsilon_{i}
$$

where $y_{i}$ is the hourly wage of individual $i, E$ is years of actual labor-market experience, ${ }^{11} G$ is a gender indicator, and $\varepsilon$ is a stochastic error. The focus of our attention is $\beta_{1}$, the earnings gradient associated with measured human capital. (We frequently refer to this simply as the "return to skill." It does not, however, correspond to a rate of return calculation, not only because of the general arguments in Heckman, Lochner, and Todd (2006) but also because we have no indication of the cost of achieving any given level of skill). To show the empirical relevance of school attainment, we will also report estimations that add attainment to this model, but it is difficult to assess whether any independent impact of school attainment implies either an impact of schooling through, say, a non-cognitive channel or through the measurement errors in cognitive skills.

More than in other empirical analyses, there is a question about the appropriate functional form of the earnings relationship. In the investment paradigm developed by Mincer (1974), a log-linear relationship between earnings and human capital is quite natural. However, as alluded to earlier, there is reason to suspect that the earnings gradient for cognitive skills is lower in early career spans and higher later. First, because skills are difficult to observe, it may take time for firms to learn about relevant differences among workers (e.g., Altonji and Pierret (2001)). Second, since early careers often involve finding the right match of skills with employers (e.g., Jovanovic (1979)), early career observations would tend to understate the full value of skills when observed in imperfect job matches. Third, Haider and Solon (2006) and Böhlmark and Lindquist (2006) show that current earnings are a good proxy for lifetime earnings only when observed between the mid-30s and late-40s. Earnings observed at earlier ages can give rise to substantial downward lifecycle bias because the measurement error at earlier ages is not of classical type, but mean-reverting: Workers with high lifetime earnings have particularly steep earnings trajectories. ${ }^{12}$ All this suggests that any empirical analysis must be sensitive to position in the career. We will therefore restrict our baseline analysis to prime-age workers and test for possible age patterns in the returns to skill.

${ }^{11}$ Although actual work experience might in part be endogenous to skill levels, robustness analyses described below indicate that results hardly change when using potential experience (age minus year of schooling minus six) instead of actual experience.

${ }^{12}$ Estimates of the intergenerational earnings elasticity have been found to double when sons' earnings are measured in their 30s rather than in their 20s; see Solon (1999) and Black and Devereux (2011) for reviews. Similar bias might be expected for estimates of the return to skills based on earnings observed early in the career. 
A caution to our direct estimation approach, however, is that none of the studies of the impact of cognitive skills on either earnings or school attainment have provided any convincing analysis of the causal impact of scores. Unlike the efforts to identify the rate of return to school attainment through a variety of means, the estimation based on measured achievement has stopped without providing any substantial evidence that the observed variation in cognitive skills is truly exogenous. The concern is that other influences on earnings - say, non-cognitive skills or direct influences of families on earnings - are omitted from the estimation, leading to standard omitted variables bias in the analysis of cognitive skills. To gauge the possible empirical relevance of such concerns, we will test for the robustness of our baseline model to additional controls such as parental education. Furthermore, to the extent that any bias of the absolute returns to skills is similar across countries, the cross-country pattern of our analysis should still give a correct picture of the relative returns to skills across countries. Nonetheless, a causal interpretation of the estimated coefficient of cognitive skills remains to be established.

Even in the absence of convincing identification strategies for cognitive skills, we believe that these estimates provide an indication of the potential earnings impacts of policies that lead to improved skills. The consistency of the estimated impacts across different model specifications and different subsamples that we will see below provides support for the underlying importance of cognitive skills, and we know of no alternative model that would consistently produce our stylized results.

\section{The PIAAC Data}

Our primary data source is the Programme for the International Assessment of Adult Competencies (PIAAC). Developed by the OECD and collected between August 2011 and March $2012,{ }^{13}$ PIAAC provides internationally comparable data about skills of the adult populations in 24 countries, ${ }^{14} 22$ of which can be used in our analysis: ${ }^{15}$ Austria, Belgium (albeit just Flanders),

\footnotetext{
${ }^{13}$ Exceptions are Canada (November 2011 to June 2012) and France (September to November 2012).

${ }^{14}$ Nine additional countries plan to implement PIAAC in 2014: Chile, Greece, Indonesia, Israel, Lithuania, New Zealand, Singapore, Slovenia, and Turkey.

${ }^{15}$ We do not use data for Australia and the Russian Federation in our analysis. The Australian data are not available to us at the time of writing. According to the OECD (2013), data for the Russian Federation are preliminary, may still be subject to change, and are not representative of the entire Russian population because they do not include the population of the Moscow municipal area. Based on the relatively small sample of 574 available observations, we estimate a return to skills of 6.8 percent in our baseline model on the available data from the Russian Federation, but this may be biased downwards by the neglect of the capital region.
} 
Canada, Cyprus, the Czech Republic, Denmark, Estonia, Finland, France, Germany, Ireland, Italy, Japan, Korea, the Netherlands, Norway, Poland, the Slovak Republic, Spain, Sweden, the United Kingdom (specifically England and Northern Ireland), and the United States.

PIAAC was designed to measure key cognitive and workplace skills needed for individuals to advance in their jobs and participate in society. In each participating country, a representative sample of adults between 16 and 65 years of age was interviewed at home in the language of their country of residence. The standard survey mode was to answer questions on a computer, but for respondents without computer experience there was also the option of a pencil-and-paper interview. ${ }^{16}$ The countries used different sampling schemes in drawing their samples, but these were all aligned to known population counts with post-sampling weightings. Our analyses employ sample weights in the estimations throughout.

The survey included an assessment of cognitive skills in three domains: literacy, numeracy, and problem solving in technology-rich environments. ${ }^{17}$ The tasks respondents had to solve were often framed as real-world problems, such as maintaining a driver's logbook (numeracy domain) or reserving a meeting room on a particular date using a reservation system (problemsolving domain). The domains, described more completely in OECD (2013), refer to key information-processing competencies and are defined as

- Literacy: ability to understand, evaluate, use and engage with written texts to participate in society, to achieve one's goals, and to develop one's knowledge and potential;

- Numeracy: ability to access, use, interpret, and communicate mathematical information and ideas in order to engage in and manage the mathematical demands of a range of situations in adult life;

- Problem solving in technology-rich environments: ability to use digital technology, communication tools and networks to acquire and evaluate information, communicate with others and perform practical tasks.

PIAAC measures each of the three skill domains on a 500-point scale. For analytical purposes, we standardize scores in the subsequent regression analyses to have a within-country

${ }^{16}$ On average across countries, 77.5 percent of assessment participants took the computer-based assessment and 22.5 percent took the paper-based assessment. A field test suggested no impact of assessment mode (OECD (2013)).

${ }^{17}$ Participation in the problem-solving domain was optional; Cyprus, France, Italy, and Spain did not participate in this domain. 
mean of zero and a within-country standard deviation of one. ${ }^{18}$ All three scales are intended to measure different dimensions of a respondent's skill set. IALS, the predecessor of PIAAC, suffered from pairwise correlations of individual skill domains that exceeded 0.9 , making it virtually impossible to distinguish between different skills. The score domains in PIAAC are less strongly correlated with an individual-level correlation between numeracy and literacy (problem-solving) of 0.85 (0.76). In our preferred empirical specification, we focus on numeracy skills, which we deem most comparable across countries, but we show below that our results do not depend on the choice of a particular measure of cognitive skills.

Before the skill assessment, all participants responded to a background questionnaire that gathered information about labor-market status, earnings, education, experience, and demographic characteristics of the respondents. The measure of experience refers to actual work experience and was collected as the number of years where at least six months were spent in paid work.

The wage measure in our baseline model refers to gross hourly earnings of wage and salary workers. In the Public Use File, earnings data for Austria, Canada, Germany, Sweden, and the United States are reported only in deciles. For Germany and the United States, we obtained access to continuous wage measures at the national data centers. For the other three countries, we obtained information on the median wage of each decile, which allows us to assign the decile median to each survey participant belonging to the respective decile of the country-specific wage distribution. In robustness specifications based on countries with continuous wage data, we show that using decile medians has no substantive impact on our results. The models that pool all countries have to rely on the Public Use File, so that the German and U.S. earnings data are also measured in deciles in the pooled regressions. In each country, we trim the bottom and top one percent of the wage distribution to limit the influence of outliers. ${ }^{19}$

To obtain a homogeneous sample of workers with strong labor-force commitment, in our baseline model we limit the estimation sample to survey respondents who work full-time at the time of the survey, where full-time employees are defined as those working at least 30 hours per week. $^{20}$ This sample decision implies that we are underestimating the impact of skills on worker

${ }^{18}$ Throughout, we use the first plausible value of the PIAAC scores in each domain.

${ }^{19}$ Preliminary investigation of outliers suggests that these largely represent data entry or coding errors.

${ }^{20}$ In Austria, the full-time working status is based on a question of whether a respondent works full-time. The Canadian sample includes full-time and part-time workers because the available data do not report working hours or work status. Since returns to skills tend to be slightly smaller when including part-time workers (17.1 vs. 17.7 percent on average across countries), this sample difference may lead to slightly conservative estimates for Canada. 
earnings to the extent that higher skills also lead to higher employment probabilities. $^{21}$

Nonetheless, we wish to isolate the direct labor-market effects of skills and to avoid other influences such as family demands, health limitations, or the like that might affect labor-force attachment. To get the best estimates of long-run returns to skills, we further restrict the baseline sample to prime-age workers, defined as those between 35 and 54 years of age. Self-employed workers are also excluded from the baseline analysis. Robustness analyses show the relevance of these sample restrictions.

Table 1 provides summary statistics for the baseline samples of prime-aged, full-time employees in the 22 countries. Sample sizes range from 816 in Poland to 1,875 in Denmark and 7,178 in Canada (which oversampled to obtain regionally reliable estimates), with a total of 34,447 observations in the pooled sample. ${ }^{22}$ Respondents in Japan achieve the highest average numeracy score, and respondents in Italy the lowest, with a difference in average achievement between these two countries amounting to 89 percent of a standard deviation in test scores in the international sample. There is also considerable variation across countries in average years of schooling, actual work experience, and the share of females in the population of prime-aged, full-time employees.

Wage inequality, measured by the log wage differential between the $90^{\text {th }}$ and $10^{\text {th }}$ percentile of the wage distribution, is largest in Estonia, Korea, and the United States at around 1.5. In these countries, a worker at the $90^{\text {th }}$ percentile of the wage distribution earns 4.5 times as much as a worker at the $10^{\text {th }}$ percentile. In Sweden, which is the other extreme, workers at the $90^{\text {th }}$ percentile earn only twice as much as workers at the $10^{\text {th }}$ percentile.

\section{Returns to Skills around the World}

Other things equal, how do earnings vary with different skills? In addressing this question, we begin with a set of baseline estimates and then investigate how these results change with modifications of the model specification or sample. Our starting point is equation (4) which

\footnotetext{
${ }^{21}$ From estimating simple linear employment probability models (available from the authors), we find that our measured skills are systematically related to higher employment.

22 Table A-1 in the Appendix reports equivalent summary statistics for the full PIAAC sample (including the full age range 16-65, part-time and self-employed workers, and the non-employed), which leads to a total sample size of 153,675 observations in the pooled international sample. The main reduction to our sample comes from restricting the age range from fifty years to twenty years (age range 35-54, reduction to 62,981), with further reductions from restricting to individuals with positive income $(45,790)$, as well as exclusion of part-time and selfemployed workers and trimming of the bottom and top one percent of the wage distribution.
} 
expresses log hourly wages as a function of numeracy skills, gender, and a quadratic polynomial in actual work experience for the sample of full-time employees aged 35-54. Since our skill measure is standardized to $(0,1)$, the parameter of interest, $\beta_{1}$, can be interpreted as the percentage increase in income associated with a one-standard-deviation increase in measured skills.

\subsection{Baseline Results}

Our baseline estimates consistently indicate that better skills are significantly related to higher labor-market earnings, as seen in Table 2. The coefficient on numeracy in the pooled estimation suggests that a one-standard-deviation increase in numeracy skills is associated with an average increase in hourly wages of 17.8 percent across the 22 countries.

But perhaps the clearest finding from our baseline estimation across countries, shown also in Figure 1, is that the wage impact of skills varies significantly across our sample of countries. Six of the countries indicate returns to skills that exceed 21 percent: the United States with almost 28 percent, Ireland and Germany with 24 percent, as well as Spain, the United Kingdom, and Korea. These high returns differ noticeably from those in another set of eight countries with returns to skills falling below 15 percent: Belgium, Cyprus, Czech Republic, Italy, and all the participating Nordic countries - Denmark, Finland, Norway, and Sweden. While a number of these countries do have significant income redistribution programs, it is important to remember that pre-tax and pre-transfer wages are being analyzed.

On average, the experience terms suggest a concave earnings-experience relationship and the gender term a male-female earnings gap in these samples of prime-aged, full-time employees. But again, there are substantial differences across countries, with no significant gender difference in earnings in four countries (Belgium, Ireland, the Netherlands, and Spain) and an earnings disadvantage of women of 20 percent and more in six countries (Cyprus, the Czech Republic, Estonia, Japan, Korea, and the Slovak Republic).

\subsection{Age Varying Returns to Skills}

As discussed, a prime motivation for this study is that most prior evidence on the return to skills has come from samples of workers that are likely to give misleading and biased estimates for the range of world economies - i.e., relying on just U.S. samples of young workers. Figure 1 shows clearly that returns to skills in the U.S. labor market might not adequately characterize the 
labor-market situation in other countries. But additionally, there are multiple reasons to believe that these estimates understate the true impact of skills across the life cycle.

To test for age varying returns to skills, Table 3 uses the extended sample of employees aged 25-65 and allows the returns to skills to differ between entry-age (25-34), prime-age (35-54), and exit-age (55-65) workers. Results suggest that there are indeed significant age differences in returns to skills: Across all countries, returns to numeracy are only 14 percent in the baseline category of workers aged 25-34 and are 4 percentage points (some 30 percent) higher among workers aged 35-54 or 55-65. In the aggregate, there are no significant differences between prime-age and exit-age workers. In fact, estimates of returns to skills increase steadily with age until age 35 and are reasonably flat from there on, getting only slightly smaller beyond age 55 (Figure 2). ${ }^{23}$ Thus, the focus on early-career earnings in the existing literature is likely to downward bias estimated returns to skills. As earnings of prime-age workers tend to be good proxies for lifetime earnings (Haider and Solon (2006)), returns estimated in the prime-age category will more likely capture lifetime returns to skills.

Looking at individual countries, returns to skills are significantly higher for prime-age workers than for entry-age workers in 15 out of the 22 countries. In all but one country (the Slovak Republic), the interaction between skills and the dummy variable indicating prime-age workers is positive. Insignificant age interactions are observed primarily in the transition economies in Eastern Europe (the Czech Republic, Estonia, Poland, and the Slovak Republic), where transition dynamics are likely to be important in explaining earnings across workers of different ages. These transition economies experienced a radical change in their labor markets after the fall of the Iron Curtain. In the process of restructuring after privatization (e.g., Frydman et al. (1999); Mertaugh and Hanushek (2005)), workers who are in their prime age or exit age today may have lost much of their specific human capital during the early 1990s and may face a job-skill mismatch, whereas workers in their entry age today may have acquired skills that are of closer labor-market relevance. Without the four Eastern European transition countries, returns to skills of prime-age and exit-age workers are even 5.0 percentage points (or 37 percent) higher than among entry-age workers (13.5 percent) in the pooled sample.

\footnotetext{
${ }^{23}$ The aggregate picture in Figure 2 might suggest including older workers in our estimates. However, past age 50 , variations in retirement and labor-force participation across countries come into play (as seen by variations in returns to exit-age workers in Table 3 ). Thus, we focus just on the prime-age worker population.
} 


\subsection{Returns to Skills and Interaction with Years of Schooling}

As discussed, our focus on measured skills differs from the standard Mincer approach of using years of schooling as the sole measure of human capital. When adding years of schooling to our baseline model, as shown in Table 4, both numeracy skills and years of schooling enter significantly in the wage equation. The point estimate on numeracy skills goes down by 43 percent (from 17.8 percent to 10.1 percent in the pooled sample), indicating that a large part of the skills-earnings relation is related to the fact that people with higher skills are more likely to advance further in the formal education system. ${ }^{24}$ In our estimation sample, the correlation between numeracy skills and years of schooling is 0.45 . Across countries, the reduction in the point estimate on numeracy skills from the inclusion of years of schooling is particularly strong (over one half) in Cyprus, Korea, Poland, the Slovak Republic, Spain, and the United States, which are the countries where the point estimates on years of schooling are particularly large.

Years of schooling enters significantly in each country, with point estimates ranging from 2.6 percent in Sweden to 9.0 percent in Poland. On average, one additional year of schooling is associated with 5.9 percent higher earnings, conditional on numeracy skills. As discussed, the independent impact of years of schooling implies either an impact of schooling through channels other than cognitive skills or through measurement errors in cognitive skills. While it is difficult to assess these possibilities, these results show the empirical importance of school attainment. Note that, compared to a standard Mincer equation without the skill measure (shown in Table A-2 in the Appendix), conditioning on numeracy skills lowers by some 20 percent the estimated returns to years of schooling from its unconditional average of 7.5 percent. Again, the drop varies considerably across countries, with the largest reduction in returns to years of schooling due to the inclusion of numeracy scores being almost one-third in Germany.

While it is difficult to compare the coefficient magnitude of our PIAAC results to estimates of returns to skill from the IALS test in the mid-1990s because previous studies have used different specifications and samples, the studies by Leuven, Oosterbeek, and Ophem (2004) and Hanushek and Zhang (2009) report somewhat similar specifications that also include both skill measures and years of schooling in one model. For the ten countries that are both in our PIAAC analysis and in their IALS analyses, the average estimated return to skills is somewhat larger in

\footnotetext{
${ }^{24}$ Results are very similar when we drop the assumption of linearity in years of schooling and instead include separate indicator variables for six levels of school attainment (see bottom row of Table A-5 in the Appendix).
} 
PIAAC than in IALS (9.1 percent here, 6.2 percent in Leuven, Oosterbeek, and Ophem (2004), and 8.1 percent in Hanushek and Zhang (2009)). ${ }^{25}$ A few particular differences to the IALS results stand out. On the one hand, our PIAAC estimates are substantially larger in Germany and in Poland (where IALS did not show any significant return to skills). On the other hand, our PIAAC estimates are smaller in the United States and (depending on the comparison study) in the Netherlands, the two countries that had the largest estimates in IALS. Closer investigation of the extent to which these comparisons are affected by differences in model specifications and samples warrants additional future research.

\subsection{Returns to Different Dimensions of Skills}

A particular innovation of the PIAAC survey is a richer measurement of various skills, both in the sense that a wider range of competencies is assessed within each skill domain and that a new skill domain was added. As noted, in contrast to the previous IALS assessments, the correlation between numeracy and literacy skills in PIAAC is somewhat lower at 0.85 , potentially allowing for an identification of the associations of each skill domain with earnings separately. Furthermore, PIAAC for the first time tested the new skill domain of problem solving in technology-rich environments ("problem solving" for short). The correlations of problem-solving skills with numeracy and literacy skills are 0.76 and 0.80 , respectively.

Table 5 reports estimates of returns to the alternative skill measures for the pooled sample, first included separately and then jointly in the model. ${ }^{26}$ By themselves, average estimated returns to literacy skills are very similar to those for numeracy skills (17.1 compared to 17.8 percent). By contrast, estimated returns to problem-solving skills are systematically smaller, at 14.3 percent on average. ${ }^{27}$ This pattern tends to be similar within most countries (see Table A-3 in the Appendix). The only partial exception to the pattern is found in Estonia, where the problemsolving estimate is larger than the literacy estimate (but not than the numeracy estimate).

Our general focus on numeracy skills comes from the joint consideration of the separate skill domains. When numeracy and literacy skills are entered together in column (4), both enter

\footnotetext{
${ }^{25}$ These comparisons refer to Table 3 in Leuven, Oosterbeek, and Ophem (2004), together with information on the standard deviation in skills from their Table A2, and to Model 4 of Table 5 in Hanushek and Zhang (2009).

${ }^{26}$ All pooled models include country fixed effects so that all estimates rely just on within-country variation.

${ }^{27}$ The number of observations in the specifications that include the problem-solving skill domain is smaller than in the baseline model because Cyprus, France, Italy, and Spain did not participate in the test of problem-solving skills and because individual respondents were allowed to opt out of the problem-solving test.
} 
significantly, but the numeracy estimates tends to dominate the literacy estimate at 12.0 percent compared to 6.8 percent on average. However, there is also some variation in this pattern across countries. In all countries except Austria, the Netherlands, and Poland, the point estimate on numeracy is larger than on literacy. While the coefficient on numeracy is statistically significant in all countries, the coefficient on literacy becomes statistically insignificant in five countries (Estonia, France, Ireland, Norway, and the Slovak Republic) and even turns negative in Japan. Of course, models that contain several skill measures at once have to be interpreted cautiously, as they are identified only from the limited part of the skill variation that is independent of variation in the other skill.

The assessment of problem solving is an innovative attempt in PIAAC to measure skills needed to succeed in an information-based economy where information and communication skills are required. ${ }^{28}$ Interestingly, these skills, at least as assessed by PIAAC, are systematically less strongly associated with individual earnings than more traditional cognitive skills. In conjunction with numeracy skills, problem solving has half the estimated return: 6.2 percent on average versus 12.1 percent for numeracy. This aggregate result holds across all countries except the Czech and Slovak Republics. Further, the point estimate on problem solving is insignificant in Japan, Korea, and Poland.

With all three skill domains together, each enters statistically significantly in the pooled model, but the point estimates on numeracy and literacy of 7.8 and 7.6 percent, respectively, are twice as large as the point estimate on problem-solving skills of 3.7 percent. Identification of separate effects is challenging in this model, particularly in the smaller within-country samples, so we do not want to over-interpret the country results. Nonetheless, while the coefficient on problem-solving skills gets small and statistically insignificant in nine of the eighteen countries, it actually dominates the numeracy estimate in three countries (the Czech and Slovak Republics and the United Kingdom) and the literacy estimate in six countries (Denmark, Estonia, Norway, the Slovak Republic, Sweden, and the United States).

The final column of Table 5 standardizes the numeracy skill measure to have mean zero and standard deviation one for the entire international sample, rather than within each country separately. This normalizes the numeracy scores to have comparable absolute returns across countries. Overall, the estimated average return to skills is slightly larger with the international

\footnotetext{
${ }^{28}$ See, for example, the description at: http://nces.ed.gov/surveys/piaac/problem-solving.asp.
} 
standardization (18.3 percent compared to 17.8 percent). In fact, in most countries this makes little difference (Table A-3), simply because within-country standard deviations in test scores are similar in many countries. But in Japan and Korea, two countries with relatively narrow withincountry skill distributions, return estimates are 3.8 and 3.1 percentage points larger, respectively, reflecting the fact that any given movement on the international distributions represents a wider within-country change. The opposite holds in the United States, the country with the widest within-country skill distribution, where return estimates are 1.7 percentage points smaller.

\subsection{Heterogeneous Returns in Different Subgroups}

In discussions of wage determination, a variety of subgroups such as females, public-sector workers, or immigrants are frequently singled out as facing different labor-market challenges. Thus, it is useful to trace through the returns to skills in such identifiable groups. To address this heterogeneity in wage determination, we added interaction terms of important subgroup indicators with the skill measure (and with all control variables) to our baseline model. Figure 3 depicts the results for the pooled estimation, with country details given in Table A-4 in the Appendix.

There are some significant differences in estimated returns to skills in the overall international sample, but the quantitative magnitude of the differences tends to be relatively modest. First, estimated returns to numeracy are nearly identical for men and women in the sample of prime-age, full-time employees. Second, estimated returns tend to slightly increase with the education level of the workers' parents (measured in three categories), but the difference ranges only from 14.8 percent for workers with low-educated parents to 18.0 percent for workers with high-educated parents. Third, estimated returns are significantly higher in the private sector (at 18.3 percent) than in the public sector, but even in the latter, returns are at 14.7 percent. Fourth, estimated returns are slightly higher in the native population (19.8 percent) than among immigrants (15.9 percent). ${ }^{29}$ The small difference indicates, among others, that the fact that interviews were performed in the country's language does not affect the overall results. Fifth, while the baseline model refers to full-time employees only, part-time employees also have a considerable return to skills, albeit significantly smaller at 12.2 percent. In the sample of fulltime and part-time employees together (not shown), the estimated return to skills is 17.1 percent.

\footnotetext{
${ }^{29}$ On average across countries, there are roughly 11 percent first-generation migrants in the sample of fulltime, prime-age employees.
} 
There are some differences for individual countries (see Table A-4). For example, returns for women exceed returns for men by more than 4 percentage points in Austria and the Czech Republic, while the opposite is true in Korea. While the advantage of private-sector returns over public-sector returns is most pronounced in Germany, Ireland, Italy, Korea, and the United Kingdom, returns are in fact slightly (albeit not significantly) higher in the public sector in Cyprus, the Czech and Slovak Republics, and Finland. Exceptions to the general rule that parttime workers have lower returns to skills than full-time workers are Belgium, Finland, and Italy. In the Czech and Slovak Republics, Denmark, Poland, and Sweden, skill returns for part-time workers are in fact very small and statistically insignificant.

\subsection{Robustness to Additional Controls and Alternative Earnings Measures}

Another way to assess the robustness of our baseline results is to include additional control variables in the model and to look at alternative measures of economic performance. As is evident from Table A-5 in the Appendix, which reports returns to skills with alternative sets of control variables, controlling for parental education reduces the estimated returns to skills only from 17.8 to 16.2 percent on average. This suggests that any direct influences of families on earnings are unlikely to be a major driver of our baseline result, easing this omitted-variable concern. Similarly, adding a migrant indicator to the baseline model hardly affects the average estimated return to skills. ${ }^{30}$

Our baseline model controls for a quadratic polynomial in actual work experience. It might be argued, though, that actual experience is endogenous to skill levels, thereby capturing a channel of the effect of skills on earnings. However, as the next model in Table A-5 shows, results are hardly different when we control for potential experience (age minus years of schooling minus six) instead of actual experience. Although estimates tend to be slightly smaller, the cross-country pattern is very similar to that obtained with actual experience.

To investigate possible channels of the effect of skills on earnings, the next model adds controls for 10 one-digit occupation (ISCO) categories. The reduction in the coefficient on skills indicates that part of the aggregate return to skills materializes through selection into higher-

\footnotetext{
${ }^{30}$ In an extended model shown in Table A-6 in the Appendix, the additional control variables are simultaneously included in the sample including part-time employees. Estimated returns to skills are smaller in all countries, but the aggregate magnitude remains large: 15.0 compared to 17.8 percent on average. The table also shows that the associations of some of the control variables with earnings differ markedly across countries.
} 
paying occupations. Still, even within occupations and ignoring any cross-occupation variation, a one-standard-deviation increase in numeracy skills is associated with a 9.6 percent wage increase on average. Controlling for 21 one-digit industry (ISIC) categories also lowers the coefficient on skills, but much less so than controlling for occupations. Even within industries, the return to skills is 15.0 percent on average, leading to the important conclusion that selection into occupations or industries explains only part of the returns to skills. Looking just within such "micro labor markets," those workers with higher skills systematically have higher wages.

Finally, the results prove highly robust in models with alternative earnings measures than the baseline specification with log gross hourly wages (Table A-7). First, in Austria, Canada, and Sweden, we do not have continuous wage information, but only the median wage of the country-specific wage decile for each participant. When we use decile medians instead of continuous wages in the other countries, estimated returns to skills are hardly different. In the pooled sample, the point estimate is 16.4 percent instead of 17.0 percent. ${ }^{31}$ Also within individual countries, results do not differ significantly. Only in the Czech Republic, Ireland, and the United States are the decile-median estimates smaller than the continuous estimates to a noteworthy extent (between 2.1 and 2.7 percentage points), whereas in several other countries, the decile-median estimates are in fact larger than the continuous estimates. The overall pattern suggests that estimates based on decile medians may be reasonable proxies for the true estimates.

Second, while our baseline wage measure does not include bonuses, models where bonuses are included in the hourly wage yield very similar estimates of skill returns that are slightly larger (17.6 instead of 17.0 percent on average). Third, considering monthly rather than hourly wages, so that hours worked come into play, hardly changes the picture (either with or without bonuses), although there is some variation for individual countries. Finally, extending the sample to the self-employed -9 percent of the labor force on average in our estimation sample also has little effect on the estimated returns across countries.

\section{Accounting for Cross-Country Differences in Returns to Skills}

In our assessment of wage determination, we have found that returns to skills differ markedly across the 22 countries in our sample. This raises the question whether there are

\footnotetext{
${ }^{31}$ All pooled models in the table exclude Austria, Canada, Germany, Sweden, and the United States, where continuous earnings data are not available in the Public Use File.
} 
features of country economies such as labor and product market regulations that are systematically related to differences in skill returns. Thus, in this final section, we turn to establishing a set of stylized facts about country characteristics that are systematically related to differences in the returns to skills across countries.

Over the past two decades, there have been significant changes in employment protection policies, unionism, and other policies across Europe. These changes have been largely motivated by a desire to improve the functioning of the economies and, by implication, the economic wellbeing of individuals. Here we investigate whether these commonly identified aspects of different countries interact with the returns to skills. For example, unions have been argued to favor wage schedules that reduce skill returns (see Frandsen (2012) and the references therein).

We begin with a baseline skill-earnings model (equation (2)) pooled across all countries and including country fixed effects $\mu_{n}$, for $n=1, \ldots, 22$ countries. We then include interaction terms between the individual skill measure $C$ and various measures of country characteristics $N$ :

$$
\ln y_{i n}=\mu_{n}+\beta_{1} C_{i n}+\beta_{2}\left(C_{i n} N_{n}\right)+\beta_{3} E_{i n}+\beta_{4} E_{i n}^{2}+\beta_{5} G_{i n}+\varepsilon_{i n}
$$

Note that the main effects of the country-level features are absorbed in the country fixed effects $\mu_{n}$. The coefficient of interest is $\beta_{2}$, which shows how returns to skills vary with different country characteristics. As the latter vary only at the country level, standard errors in this model are clustered at the country level. While degrees of freedom are limited in such a cross-country analysis, the extended PIAAC sample provides substantially more analytical potential than previous studies. Note that any bias in estimated returns to skills that is the same across countries would not affect this analysis, which is identified from the relative returns across countries. To facilitate interpretation, all variables in the interacted model are de-meaned.

For this analysis, we incorporate aggregate data about differences in the structure of the international economies. ${ }^{32}$ Union density measures the share of wage and salary earners who are trade union members. Employment protection legislation indicates the strictness of employment

\footnotetext{
${ }^{32}$ Data are provided by the OECD and refer to 2011 unless otherwise noted. Union density refers to 2009 in the Czech Republic and to 2010 in Denmark, Estonia, Poland, and Spain. The employment-protection indicator is the weighted sum of sub-indicators concerning the regulations for individual dismissals (weight of 5/7) and additional provisions for collective dismissals (2/7), incorporating 13 data items (see Venn (2009) for details). The product-market regulation indicator refers to 2008 and covers formal regulations in state control of business enterprises, legal and administrative barriers to entrepreneurship, and barriers to international trade and investment (see Wölfl et al. (2009) for details). Results are similar when using other measures of employment protection legislation or sub-indices of product-market regulation. The public-sector share is calculated from the PIAAC data.
} 
protection against individual and collective dismissal of employees on regular contracts. Existence of minimum wages is measured by a binary variable that takes the value 1 if a country has a statutory minimum wage and 0 otherwise. Product-market regulation is a composite indicator measuring the degree to which policies promote or inhibit competition in areas of the product market where competition is viable. Public-sector share is the share of wage and salary workers employed in the public sector.

Analysis of the various aggregate institutional factors produces an interesting pattern of results (Table 6). When entered separately, union density, employment protection, and the public-sector share have significant negative interactions with the returns to skill. That is, countries with a larger share of unionized workers, stricter employment protection, and larger public sectors have systematically lower returns to skills on the labor market. For example, the estimate in column (1) suggests that a 25 percentage-point increase in union density (the difference, for example, between Belgium and the United Kingdom) is associated with a 3.5 percentage points lower wage increase for each one-standard-deviation increase in numeracy skills. By contrast, product-market regulations are not significantly related to differences in returns to skills across countries, whereas countries with a minimum wage in fact appear to have larger returns to skill in this simple model. However, when all five country-level measures are jointly included in column (6), only the interactions with union density and employment protection legislation retain significance.

To ensure that results are not driven by country differences in the level or dispersion of skills, column (7) adds interactions with the mean numeracy score of the country and with skill inequality (the differential between the $90^{\text {th }}$ and $10^{\text {th }}$ percentile of the numeracy skill distribution). The skill level may capture the supply of skills within a country, while skill inequality reflects how compressed the distribution of skills is. It turns out that neither countries' skill means nor their skill inequalities are significantly related to differences in returns to skills, and the previous results remain intact.

Finally, column (8) adds a full set of 185 occupation-by-industry fixed effects to check whether results are driven by differences in the occupation or industry structures of countries. Identification in this model comes from variation within rather detailed industry-occupation cells. Even in this quite demanding specification, the results on the interactions of returns to skill with union density and with employment protection remain intact. In addition, the interaction 
with the public-sector share recovers significance in this model. We conclude that returns to skills are systematically lower in countries with higher union density, stricter employment protection legislation, and larger public sectors.

\section{Conclusions}

While human capital is virtually always identified as the key factor determining systematic differences in individual wages, existing empirical evidence has rested on crude and (almost certainly) biased estimates of its importance. The ubiquitous Mincer earnings function assumes that skill differences can be encapsulated in measures of school attainment, neglecting any other factors that might systematically affect skills. When direct measures of skill differences are introduced, the bulk of evidence on the returns to skills is restricted to selective samples - namely, young workers in the United States. These samples are, as we demonstrate, unrepresentative both of the labor-market experiences in other countries and of older, prime-age workers. We investigate the returns associated with a series of measures of cognitive skills across a large set of countries. The new international PIAAC study provides insights into the extent to which modern, knowledge-based labor markets reward skills.

Higher cognitive skills - measured across numeracy, literacy, and problem-solving domains - are systematically related to higher wages in all 22 participating countries. The effect sizes of our returns to skills estimates (best thought of as lower bounds because of measurement errors in skills) are economically meaningful. Among prime-age workers, a one-standard-deviation increase in numeracy skills is associated with increased hourly wages averaging some 18 percent across countries. But perhaps the most striking finding from the international analysis is the substantial heterogeneity in returns to skills across countries. Estimated returns to skills in the countries with the highest returns (the United States, Ireland, and Germany) are roughly twice as large as in the countries with the lowest returns (Sweden, the Czech Republic, and Norway).

In addition, the age pattern of returns underscores the problem of relying just on the experiences of younger workers in evaluating the economic role of skill differences. Prime-age workers (age 35-54) quite consistently show greater returns to skills than labor-market entrants (age 25-34), averaging a 4 percentage-point difference. Only the participating Eastern European transition economies fail to show this age pattern, probably reflecting the loss of human capital to older workers when their economies changed. 
The skill-earnings associations prove immensely robust in a variety of dimensions when looking at the labor-market earnings of prime-age workers. Perhaps surprisingly, though, returns to general literacy and particularly numeracy are quite consistently higher than returns to problem solving, a construct developed to measure skill demands in technologically-based economies. Differences in returns to skills across subsets of workers also present interesting patterns. On average, women and men have identical returns, while observed skills make somewhat less difference to immigrants, part-time workers, and public-sector workers. Again, however, there are country differences that warrant more investigation.

Having established the pattern of returns to skills across countries, the cross-country dimension of our analysis allows us to provide stylized facts about what accounts for differences in returns to skills across countries. Intriguingly, returns to skills are systematically lower in countries with higher union density, stricter employment protection legislation, and larger public sectors, while minimum wages, product-market regulations, average skill levels, and skill inequality are not systematically related to differences in skill returns. While this is just a descriptive depiction of which countries have higher skill returns than others, the consistency with standard conceptual models is striking.

The regularity of the relationship between cognitive skills and higher earnings in all countries documents the extent to which modern knowledge-based economies value skills. We view the results presented here as a building block toward better understanding the sources and mechanisms that relate individuals' skills to productivity and labor-market outcomes. For example, by quantifying this association, the new results may have immediate application in parameterizing development-accounting studies that try to quantify the extent to which crosscountry differences in skills can account for cross-country differences in economic prosperity (Caselli (2005); Hanushek and Woessmann (2012)). Additionally, understanding individual productivity differences is a necessary ingredient into projecting how the average level and inequality of economic outcomes of countries may move with future technological change.

Importantly, almost all international discussion of educational policy is centered on school quality and student achievement. To understand the full economic implications of these discussions, it is necessary to move the analysis of labor-market outcomes to match the analysis of school outcomes. 


\section{References}

Acemoglu, Daron, and David Autor. 2011. "Skills, tasks and technologies: Implications for employment and earnings." In Handbook of Labor Economics, Volume 4b, edited by Orley Ashenfelter and David Card. Amsterdam: North Holland: 1043-1171.

Altonji, Joseph G., and Charles R. Pierret. 2001. "Employer learning and statistical discrimination." Quarterly Journal of Economics 116, no. 1: 313-350.

Autor, David H., Frank Levy, and Richard J. Murnane. 2003. "The skill content of recent technological change: An empirical exploration." Quarterly Journal of Economics 118, no. 4: 1279-1333.

Barone, Carlo, and Herman G van de Werfhorst. 2011. "Education, cognitive skills and earnings in comparative perspective." International Sociology 26, no. 4: 483-502.

Bishop, John H. 1989. "Is the test score decline responsible for the productivity growth decline?" American Economic Review 79, no. 1: 178-197.

Black, Sandra E., and Paul J. Devereux. 2011. "Recent developments in intergenerational mobility." In Handbook of Labor Economics, Vol. 4b, edited by Orley Ashenfelter and David Card. Amsterdam: North Holland: 1487-1541.

Böhlmark, Anders, and Matthew J. Lindquist. 2006. "Life-cycle variations in the association between current and lifetime income: Replication and extension for Sweden." Journal of Labor Economics 24, no. 4: 879-896.

Bowles, Samuel, Herbert Gintis, and Melissa Osborne. 2001. "The determinants of earnings: A behavioral approach." Journal of Economic Literature 39, no. 4: 1137-1176.

Card, David. 1999. "The causal effect of education on earnings." In Handbook of Labor Economics, Vol. 3a, edited by Orley Ashenfelter and David Card. Amsterdam: North Holland: 1801-1863.

Caselli, Francesco. 2005. "Accounting for cross-country income differences." In Handbook of Economic Growth, edited by Philippe Aghion and Steven N. Durlauf. Amsterdam: North Holland: 679-741.

Chetty, Raj, John N. Friedman, Nathaniel Hilger, Emmanuel Saez, Diane Whitmore Schanzenbach, and Danny Yagan. 2011. "How does your kindergarten classroom affect your earnings? Evidence from Project STAR." Quarterly Journal of Economics 126, no. 4: 1593-1660.

Cunha, Flavio, and James Heckman. 2007. "The technology of skill formation." American Economic Review 97, no. 2: 31-47.

Cunha, Flavio, James J. Heckman, Lance Lochner, and Dimitriy V. Masterov. 2006. "Interpreting the evidence on life cycle skill formation." In Handbook of the Economics of Education, edited by Eric A. Hanushek and Finis Welch. Amsterdam: North Holland: 697-812.

Denny, Kevin, Colm Harmon, and Vincent O'Sullivan. 2004. "Education, earnings and skills: A multi-country comparison." IFS Working Paper 04/08. London: Institute for Fiscal Studies.

Dugan, Dennis J. 1976. "Scholastic achievement: its determinants and effects in the education industry." In Education as an industry, edited by Joseph T. Froomkin, Dean T. Jamison, and Roy Radner. Cambridge, MA: Ballinger: 53-83. 
Frandsen, Brigham R. 2012. "Why unions still matter: The effects of unionization on the distribution of employee earnings." Manuscript. Cambridge, MA: MIT.

Frydman, Roman, Cheryl Gray, Marek Hessel, and Andrzej Rapaczynski. 1999. "When does privatization work? The impact of private ownership on corporate performance in the transition economies." Quarterly Journal of Economics 114, no. 4: 1153-1191.

Goldin, Claudia, and Lawrence F. Katz. 2008. The race between education and technology. Cambridge, MA: Harvard University Press.

Green, David A., and W. Craig Riddell. 2003. "Literacy and earnings: An investigation of the interaction of cognitve and unobsrved skills in earnings generation." Labour Economics 10, no. 2: $165-184$.

Green, David A., and W. Craig Riddell. 2013. "Ageing and literacy skills: Evidence from Canada, Norway and the United States." Labour Economics 22, no. 2: 16-29.

Griliches, Zvi. 1977. "Estimating the returns to schooling: Some econometric problems." Econometrica 45, no. 1: 1-22.

Haider, Steven, and Gary Solon. 2006. "Life-cycle variation in the association between current and lifetime earnings." American Economic Review 96, no. 4: 1308-1320.

Hanushek, Eric A. 2002. "Publicly provided education." In Handbook of Public Economics, Vol. 4, edited by Alan J. Auerbach and Martin Feldstein. Amsterdam: North Holland: 2045-2141.

Hanushek, Eric A., and Steven G. Rivkin. 2012. "The distribution of teacher quality and implications for policy." Annual Review of Economics 4: 131-157.

Hanushek, Eric A., and Ludger Woessmann. 2008. "The role of cognitive skills in economic development." Journal of Economic Literature 46, no. 3: 607-668.

Hanushek, Eric A., and Ludger Woessmann. 2011. "The economics of international differences in educational achievement." In Handbook of the Economics of Education, Vol. 3, edited by Eric A. Hanushek, Stephen Machin, and Ludger Woessmann. Amsterdam: North Holland: 89-200.

Hanushek, Eric A., and Ludger Woessmann. 2012. "Schooling, educational achievement, and the Latin American growth puzzle." Journal of Development Economics 99, no. 2: 497-512.

Hanushek, Eric A., and Lei Zhang. 2009. "Quality-consistent estimates of international schooling and skill gradients." Journal of Human Capital 3, no. 2: 107-143.

Harmon, Colm, Hessel Oosterbeek, and Ian Walker. 2003. "The returns to education: Microeconomics." Journal of Economic Surveys 17, no. 2: 115-155.

Hause, John C. 1972. "Earnings profile: Ability and schooling." Journal of Political Economy 80, no. 3, pt. 2: S108-S138.

Heckman, James J., Lance J. Lochner, and Petra E. Todd. 2006. "Earnings functions, rates of return and treatment effects: The Mincer equation and beyond." In Handbook of the Economics of Education, Vol. 1, edited by Eric A. Hanushek and Finis Welch. Amsterdam: North Holland: 307-458.

Jovanovic, Boyan. 1979. "Job matching and the theory of turnover." Journal of Political Economy 87, no. 5: 972-990. 
Lazear, Edward P. 2003. "Teacher incentives." Swedish Economic Policy Review 10, no. 3: 179214.

Leuven, Edwin, Hessel Oosterbeek, and Hans van Ophem. 2004. "Explaining international differences in male skill wage differentials by differences in demand and supply of skills." Economic Journal 114, no. 495: 466-486.

Manski, Charles F., and David A. Wise. 1983. College choice in America. Cambridge: Harvard University Press.

McIntosh, Steven, and Anna Vignoles. 2001. "Measuring and assessing the impact of basic skills on labor market outcomes." Oxford Economic Papers 53, no. 3: 453-481.

Mertaugh, Michael, and Eric A. Hanushek. 2005. "Education and training." In Labor markets and social policy in Central and Eastern Europe: The accession and beyond, edited by Nicholas Barr. Washington, DC: World Bank: 207-251.

Mincer, Jacob. 1970. "The distribution of labor incomes: a survey with special reference to the human capital approach." Journal of Economic Literature 8, no. 1: 1-26.

Mincer, Jacob. 1974. Schooling, experience, and earnings. New York: NBER.

Mulligan, Casey B. 1999. "Galton versus the human capital approach to inheritance." Journal of Political Economy 107, no. 6, pt. 2: S184-S224.

Murnane, Richard J., John B. Willett, Yves Duhaldeborde, and John H. Tyler. 2000. "How important are the cognitive skills of teenagers in predicting subsequent earnings?" Journal of Policy Analysis and Management 19, no. 4: 547-568.

Murnane, Richard J., John B. Willett, and Frank Levy. 1995. "The growing importance of cognitive skills in wage determination." Review of Economics and Statistics 77, no. 2: 251-266.

Neal, Derek, and William R. Johnson. 1996. "The role of pre-market factors in black-white differences." Journal of Political Economy 104, no. 5: 869-895.

OECD. 2013. OECD skills outlook 2013: First results from the survey of adult skills. Paris: Organisation for Economic Co-operation and Development.

Psacharopoulos, George, and Harry A. Patrinos. 2004. "Returns to investment in education: a further update." Education Economics 12, no. 2: 111-134.

Rivkin, Steven G. 1995. "Black/white differences in schooling and employment." Journal of Human Resources 30, no. 4: 826-852.

Solon, Gary. 1999. "Intergenerational mobility in the labor market." In Handbook of Labor Economics, Vol. $3 a$, edited by Orley Ashenfelter and David Card. Amsterdam: North Holland: 1761-1800.

Venn, Danielle. 2009. "Legislation, collective bargaining and enforcement: Updating the OECD employment protection indicators." OECD Social, Employment and Migration Working Paper 89. Paris: OECD.

Wölfl, Anita, Isabelle Wanner, Tomasz Kozluk, and Giuseppe Nicoletti. 2009. "Ten years of product market reform in OECD countries: Insights from a revised PMR indicator." OECD Economics Department Working Paper 695. Paris: OECD. 
Table A-1: Descriptive Statistics in the Full Sample

\begin{tabular}{|c|c|c|c|c|c|c|c|c|c|c|c|c|}
\hline & Pooled & Austria & Belgium & Canada & Cyprus & Czech R. & Denmark & Estonia & Finland & France & Germany & Ireland \\
\hline $\begin{array}{l}\text { Gross hourly wage } \\
\text { (national currency) }\end{array}$ & & $\begin{array}{l}13.5 \\
(5.9)\end{array}$ & $\begin{array}{l}17.0 \\
(6.3)\end{array}$ & $\begin{array}{c}24.1 \\
(11.9)\end{array}$ & $\begin{array}{l}11.0 \\
(6.6)\end{array}$ & $\begin{array}{l}120.4 \\
(57.6)\end{array}$ & $\begin{array}{l}179.7 \\
(68.0)\end{array}$ & $\begin{array}{l}5.1 \\
(3.2)\end{array}$ & $\begin{array}{l}17.0 \\
(6.4)\end{array}$ & $\begin{array}{l}12.9 \\
(5.6)\end{array}$ & $\begin{array}{l}14.3 \\
(7.2)\end{array}$ & $\begin{array}{l}17.7 \\
(9.6)\end{array}$ \\
\hline Wage inequality & 1.12 & 1.07 & 0.85 & 1.25 & 1.26 & 0.96 & 0.78 & 1.51 & 0.88 & 0.86 & 1.35 & 1.20 \\
\hline Numeracy & $\begin{array}{l}268.5 \\
(52.5)\end{array}$ & $\begin{array}{l}274.9 \\
(49.1)\end{array}$ & $\begin{array}{l}280.2 \\
(51.4)\end{array}$ & $\begin{array}{l}265.7 \\
(55.9)\end{array}$ & $\begin{array}{l}263.8 \\
(46.7)\end{array}$ & $\begin{array}{l}275.3 \\
(43.8)\end{array}$ & $\begin{array}{l}277.9 \\
(51.2)\end{array}$ & $\begin{array}{l}272.8 \\
(45.2)\end{array}$ & $\begin{array}{l}282.4 \\
(52.2)\end{array}$ & $\begin{array}{l}254.0 \\
(56.5)\end{array}$ & $\begin{array}{l}272.4 \\
(52.7)\end{array}$ & $\begin{array}{l}255.5 \\
(53.7)\end{array}$ \\
\hline Yrs schooling & $\begin{array}{l}12.5 \\
(3.1)\end{array}$ & $\begin{array}{l}11.8 \\
(2.7)\end{array}$ & $\begin{array}{l}12.3 \\
(2.9)\end{array}$ & $\begin{array}{l}13.2 \\
(2.7)\end{array}$ & $\begin{array}{l}12.3 \\
(3.1)\end{array}$ & $\begin{array}{l}13.0 \\
(2.7)\end{array}$ & $\begin{array}{l}12.5 \\
(2.7)\end{array}$ & $\begin{array}{l}12.1 \\
(2.7)\end{array}$ & $\begin{array}{l}12.2 \\
(3.0)\end{array}$ & $\begin{array}{l}11.2 \\
(3.6)\end{array}$ & $\begin{array}{l}13.0 \\
(3.0)\end{array}$ & $\begin{array}{l}14.5 \\
(3.2)\end{array}$ \\
\hline Experience (years) & $\begin{array}{l}18.7 \\
(12.8)\end{array}$ & $\begin{array}{l}20.0 \\
(12.6)\end{array}$ & $\begin{array}{l}20.8 \\
(12.5)\end{array}$ & $\begin{array}{l}19.3 \\
(12.7)\end{array}$ & $\begin{array}{l}17.5 \\
(12.3)\end{array}$ & $\begin{array}{l}20.0 \\
(12.9)\end{array}$ & $\begin{array}{l}21.0 \\
(13.7)\end{array}$ & $\begin{array}{l}19.0 \\
(13.0)\end{array}$ & $\begin{array}{l}19.0 \\
(13.6)\end{array}$ & $\begin{array}{l}19.4 \\
(13.2)\end{array}$ & $\begin{array}{l}19.2 \\
(13.0)\end{array}$ & $\begin{array}{c}17.0 \\
(12.0)\end{array}$ \\
\hline Female (share) & 0.50 & 0.50 & 0.50 & 0.50 & 0.52 & 0.50 & 0.50 & 0.52 & 0.50 & 0.51 & 0.50 & 0.51 \\
\hline Observations & 153675 & 5130 & 5463 & 26683 & 5053 & 6102 & 7328 & 7632 & 5464 & 6993 & 5465 & 5983 \\
\hline & & Italy & Japan & Korea & Netherl. & Norway & Poland & Slovak R. & Spain & Sweden & U.K. & U.S. \\
\hline $\begin{array}{l}\text { Gross hourly wage } \\
\text { (national currency) }\end{array}$ & & $\begin{array}{l}11.5 \\
(6.0)\end{array}$ & $\begin{array}{c}1.6^{\dagger} \\
(1.1)\end{array}$ & $\begin{array}{l}13.6^{\dagger} \\
(11.5)\end{array}$ & $\begin{array}{l}16.5 \\
(7.6)\end{array}$ & $\begin{array}{l}211.9 \\
(78.1)\end{array}$ & $\begin{array}{l}16.6 \\
(10.0)\end{array}$ & $\begin{array}{l}4.4 \\
(3.2)\end{array}$ & $\begin{array}{l}9.8 \\
(5.1)\end{array}$ & $\begin{array}{l}162.3 \\
(48.8)\end{array}$ & $\begin{array}{l}12.1 \\
(7.3)\end{array}$ & $\begin{array}{l}21.0 \\
(13.8)\end{array}$ \\
\hline Wage inequality & & 1.02 & 1.31 & 1.50 & 1.06 & 0.80 & 1.25 & 1.22 & 1.21 & 0.69 & 1.20 & 1.49 \\
\hline Numeracy & & $\begin{array}{l}247.0 \\
(50.2)\end{array}$ & $\begin{array}{l}288.6 \\
(43.7)\end{array}$ & $\begin{array}{l}262.7 \\
(45.3)\end{array}$ & $\begin{array}{l}280.1 \\
(51.4)\end{array}$ & $\begin{array}{l}278.6 \\
(55.1)\end{array}$ & $\begin{array}{l}258.9 \\
(50.9)\end{array}$ & $\begin{array}{l}275.6 \\
(47.2)\end{array}$ & $\begin{array}{l}245.6 \\
(51.4)\end{array}$ & $\begin{array}{l}278.1 \\
(54.9)\end{array}$ & $\begin{array}{l}262.2 \\
(54.8)\end{array}$ & $\begin{array}{l}253.0 \\
(57.1)\end{array}$ \\
\hline Yrs schooling & & $\begin{array}{l}10.5 \\
(3.9)\end{array}$ & $\begin{array}{l}12.9 \\
(2.4)\end{array}$ & $\begin{array}{l}12.6 \\
(3.2)\end{array}$ & $\begin{array}{l}13.1 \\
(2.8)\end{array}$ & $\begin{array}{l}13.9 \\
(2.6)\end{array}$ & $\begin{array}{l}12.5 \\
(3.1)\end{array}$ & $\begin{array}{l}12.9 \\
(2.8)\end{array}$ & $\begin{array}{l}11.3 \\
(3.5)\end{array}$ & $\begin{array}{l}12.0 \\
(2.5)\end{array}$ & $\begin{array}{l}13.0 \\
(2.2)\end{array}$ & $\begin{array}{l}13.3 \\
(3.1)\end{array}$ \\
\hline Experience (years) & & $\begin{array}{c}18.1 \\
(12.3)\end{array}$ & $\begin{array}{l}18.8 \\
(12.7)\end{array}$ & $\begin{array}{l}13.2 \\
(10.8)\end{array}$ & $\begin{array}{l}18.7 \\
(12.4)\end{array}$ & $\begin{array}{l}18.7 \\
(12.8)\end{array}$ & $\begin{array}{l}17.0 \\
(12.5)\end{array}$ & $\begin{array}{l}19.1 \\
(12.5)\end{array}$ & $\begin{array}{l}17.4 \\
(12.1)\end{array}$ & $\begin{array}{l}19.3 \\
(13.8)\end{array}$ & $\begin{array}{c}19.6 \\
(13.0)\end{array}$ & $\begin{array}{c}19.4 \\
(13.2)\end{array}$ \\
\hline Female (share) & & 0.50 & 0.50 & 0.50 & 0.50 & 0.49 & 0.51 & 0.50 & 0.50 & 0.49 & 0.50 & 0.51 \\
\hline Observations & & 4621 & 5278 & 6667 & 5170 & 5128 & 9366 & 5723 & 6055 & 4469 & 8892 & 5010 \\
\hline
\end{tabular}

Notes: Means, standard deviations (in parentheses), and numbers of observations for selected variables by country. Sample: full PIAAC sample (ages 16-65). Wage inequality: log wage differential between 90th and 10th percentile of wage distribution. Pooled specification gives same weight to each country. ${ }^{\dagger}$ wages divided by 1000 . Data source: PIAAC. 
Table A-2: Standard Mincerian Wage Regressions

\begin{tabular}{|c|c|c|c|c|c|c|c|c|c|c|c|c|}
\hline & Pooled & Austria & Belgium & Canada & Cyprus & Czech R. & Denmark & Estonia & Finland & France & Germany & Ireland \\
\hline \multirow[t]{2}{*}{ Yrs schooling } & $.075^{* * *}$ & $.077^{* * *}$ & $.062^{* * *}$ & $.078^{* * *}$ & $.089^{* * *}$ & $.059^{* * *}$ & $.055^{* * *}$ & $.074^{* * *}$ & $.068^{* * *}$ & $.055^{* * *}$ & $.095^{* * *}$ & $.085^{* * *}$ \\
\hline & $(.001)$ & $(.004)$ & $(.003)$ & (.003) & $(.006)$ & $(.008)$ & $(.003)$ & $(.005)$ & $(.003)$ & (.002) & $(.005)$ & $(.007)$ \\
\hline \multirow[t]{2}{*}{ Experience } & $.027^{* * *}$ & $.027^{* * *}$ & $.018^{* * *}$ & $.029^{* * *}$ & $.023^{* * *}$ & .014 & $.011^{* * *}$ & $.025^{* * *}$ & $.019^{* * *}$ & $.021^{* * *}$ & $.015^{*}$ & $.040^{* * *}$ \\
\hline & (.001) & $(.007)$ & $(.006)$ & (.004) & $(.008)$ & $(.009)$ & (.004) & (.009) & $(.005)$ & $(.005)$ & $(.008)$ & $(.010)$ \\
\hline \multirow[t]{2}{*}{ Experience $^{2}$} & $-.042^{* * *}$ & $-.040^{* * *}$ & -.020 & $-.041^{* * *}$ & -.014 & -.028 & -.014 & $-.072^{* * *}$ & $-.026^{* *}$ & $-.026^{* *}$ & -.016 & $-.061^{* * *}$ \\
\hline & (.003) & $(.014)$ & $(.013)$ & $(.008)$ & (.019) & (.020) & $(.009)$ & (.020) & (.012) & $(.011)$ & $(.018)$ & (.023) \\
\hline \multirow[t]{2}{*}{ Female } & $-.200^{* * *}$ & $-.140^{* * *}$ & $-.078^{* * *}$ & $-.160^{* * *}$ & $-.204^{* * *}$ & $-.216^{* * *}$ & $-.135^{* * *}$ & $-.470^{* * *}$ & $-.228^{* * *}$ & $-.136^{* * *}$ & $-.163^{* * *}$ & $-.077^{* *}$ \\
\hline & $(.005)$ & (.023) & $(.017)$ & $(.015)$ & (.033) & (.032) & $(.013)$ & $(.024)$ & $(.015)$ & $(.016)$ & $(.025)$ & (.033) \\
\hline $\mathrm{R}^{2}$ & .272 & .295 & .238 & .243 & .306 & .236 & .236 & .277 & .375 & .293 & .274 & .233 \\
\hline \multirow[t]{2}{*}{ Observations } & 34161 & 1115 & 1219 & 7155 & 938 & 1065 & 1877 & 1767 & 1478 & 1707 & 1296 & 1031 \\
\hline & & Italy & Japan & Korea & Netherl. & Norway & Poland & Slovak R. & Spain & Sweden & U.K. & U.S. \\
\hline \multirow[t]{2}{*}{ Yrs schooling } & & $.053^{* * *}$ & $.088^{* * *}$ & $.093^{* * *}$ & $.082^{* * *}$ & $.056^{* * *}$ & $.101^{* * *}$ & $.095^{* * *}$ & $.079^{* * *}$ & $.042^{* * *}$ & $.085^{* * *}$ & $.111^{* * *}$ \\
\hline & & $(.004)$ & $(.005)$ & $(.005)$ & $(.005)$ & $(.003)$ & $(.005)$ & $(.006)$ & $(.003)$ & (.003) & $(.006)$ & $(.005)$ \\
\hline \multirow[t]{2}{*}{ Experience } & & $.014^{* *}$ & $.028^{* * *}$ & $.027^{* * *}$ & $.036^{* * *}$ & $.029^{* * *}$ & $.028^{* * *}$ & .017 & $.027^{* * *}$ & $.020^{* * *}$ & $.029^{* * *}$ & $.022^{* * *}$ \\
\hline & & $(.007)$ & $(.008)$ & $(.005)$ & $(.007)$ & $(.005)$ & (.007) & $(.012)$ & $(.007)$ & $(.005)$ & $(.010)$ & $(.008)$ \\
\hline \multirow[t]{2}{*}{ Experience $^{2}$} & & .001 & -.025 & $-.025^{*}$ & $-.064^{* * *}$ & $-.055^{* * *}$ & $-.046^{* * *}$ & -.031 & $-.038^{* *}$ & $-.036^{* * *}$ & $-.052^{* *}$ & $-.039^{* *}$ \\
\hline & & (.017) & $(.018)$ & $(.015)$ & $(.015)$ & (.012) & $(.017)$ & $(.027)$ & $(.015)$ & (.010) & (.021) & $(.017)$ \\
\hline \multirow[t]{2}{*}{ Female } & & $-.174^{* * *}$ & $-.337^{* * *}$ & $-.322^{* * *}$ & $-.058^{* *}$ & $-.160^{* * *}$ & $-.228^{* * *}$ & $-.290^{* * *}$ & $-.145^{* * *}$ & $-.132^{* * *}$ & $-.158^{* * *}$ & $-.265^{* * *}$ \\
\hline & & $(.026)$ & $(.025)$ & (.028) & $(.024)$ & $(.014)$ & $(.028)$ & $(.028)$ & $(.024)$ & $(.014)$ & (.028) & (.024) \\
\hline $\mathrm{R}^{2}$ & & .264 & .345 & .419 & .279 & .250 & .394 & .305 & .365 & .189 & .198 & .384 \\
\hline Observations & & 1018 & 1322 & 1441 & 1013 & 1519 & 816 & 1198 & 1190 & 1316 & 1671 & 983 \\
\hline
\end{tabular}

Notes: Least squares regressions weighted by sampling weights. Dependent variable: log gross hourly wage. Sample: full-time employees aged 35-54 (Canada includes part-time employees). Experience ${ }^{2}$ divided by 1000. Pooled specification includes country fixed effects and gives same weight to each country; $\mathrm{R}^{2}$ refers to within-country $\mathrm{R}^{2}$. Robust standard errors in parentheses. Data source: PIAAC. 
Table A-3: Returns to Skills for Alternative Skill Measures: Numeracy, Literacy, and Problem Solving

\begin{tabular}{|c|c|c|c|c|c|c|c|c|c|c|c|c|}
\hline & Pooled & Austria & Belgium & Canada & Cyprus & Czech R. & Denmark & Estonia & Finland & France & Germany & Ireland \\
\hline \multirow[t]{2}{*}{ Numeracy } & $.178^{* * *}$ & $.179^{* * *}$ & $.149^{* * *}$ & $.193^{* * *}$ & $.138^{* * *}$ & $.124^{* * *}$ & $.137^{* * *}$ & $.179^{* * *}$ & $.142^{* * *}$ & $.174^{* * *}$ & $.235^{* * *}$ & $.241^{* * *}$ \\
\hline & $(.003)$ & $(.010)$ & $(.009)$ & $(.008)$ & $(.019)$ & $(.015)$ & $(.008)$ & (.012) & $(.010)$ & $(.008)$ & $(.013)$ & $(.020)$ \\
\hline \multirow[t]{2}{*}{ Literacy } & $.171^{* * *}$ & $.186^{* * *}$ & $.150^{* * *}$ & $192^{* * *}$ & $126^{* * *}$ & $.123^{* * *}$ & $.139^{* * *}$ & $.138^{* * *}$ & $133^{* * *}$ & $.151^{* * *}$ & $.233^{* * *}$ & $.215^{* * *}$ \\
\hline & (.003) & $(.010)$ & $(.009)$ & $(.007)$ & $(.017)$ & $(.015)$ & $(.008)$ & $(.013)$ & $(.011)$ & $(.009)$ & $(.013)$ & $(.021)$ \\
\hline \multirow[t]{2}{*}{ Problem solv. } & $.143^{* * *}$ & $.143^{* * *}$ & $.118^{* * *}$ & $140^{* * *}$ & & $.110^{* * *}$ & $.119^{* * *}$ & $.165^{* * *}$ & $.123^{* * *}$ & & $.185^{* * *}$ & $.167^{* * *}$ \\
\hline & $(.003)$ & $(.013)$ & $(.010)$ & $(.008)$ & & $(.016)$ & $(.008)$ & $(.015)$ & $(.009)$ & & $(.013)$ & $(.019)$ \\
\hline \multirow[t]{2}{*}{ Numeracy } & $.120^{* * *}$ & $.079^{* * *}$ & $.081^{* * *}$ & $101^{* * *}$ & $.089^{* * *}$ & $.078^{* * *}$ & $.082^{* * *}$ & $201^{* * *}$ & $.107^{* * *}$ & $.163^{* * *}$ & $.130^{* * *}$ & $.185^{* * *}$ \\
\hline & $(.005)$ & $(.020)$ & $(.018)$ & $(.016)$ & $(.027)$ & $(.024)$ & $(.016)$ & $(.021)$ & $(.016)$ & $(.017)$ & $(.026)$ & $(.040)$ \\
\hline \multirow[t]{2}{*}{ Literacy } & $.068^{* * *}$ & $.117^{* * *}$ & $.078^{* * *}$ & $.106^{* * *}$ & $.061^{* *}$ & $.062^{* *}$ & $.066^{* * *}$ & -.027 & $.041^{* *}$ & .012 & $.121^{* * *}$ & .062 \\
\hline & $(.005)$ & $(.020)$ & $(.019)$ & $(.016)$ & $(.024)$ & $(.025)$ & $(.016)$ & $(.021)$ & $(.018)$ & $(.017)$ & $(.026)$ & $(.040)$ \\
\hline \multirow[t]{2}{*}{ Numeracy } & $.121^{* * *}$ & $.117^{* * *}$ & $.119^{* * *}$ & $.134^{* * *}$ & & .038 & $.078^{* * *}$ & $.098^{* * *}$ & $.122^{* * *}$ & & $.184^{* * *}$ & $.167^{* * *}$ \\
\hline & $(.005)$ & $(.021)$ & $(.015)$ & $(.014)$ & & $(.025)$ & $(.015)$ & $(.026)$ & $(.014)$ & & $(.024)$ & (.033) \\
\hline \multirow[t]{2}{*}{ Problem solv. } & $.062^{* * *}$ & $.068^{* * *}$ & $.035^{* *}$ & $.051^{* * *}$ & & $.085^{* * *}$ & $.064^{* * *}$ & $.088^{* * *}$ & $.036^{* * *}$ & & $.055^{* *}$ & $.058^{* *}$ \\
\hline & $(.005)$ & $(.018)$ & $(.015)$ & $(.012)$ & & $(.021)$ & $(.014)$ & $(.026)$ & $(.014)$ & & $(.021)$ & $(.029)$ \\
\hline \multirow[t]{2}{*}{ Numeracy } & $.078^{* * *}$ & .042 & $.069^{* * *}$ & $.077^{* * *}$ & & -.002 & $.058^{* * *}$ & $.088^{* * *}$ & $.088^{* * *}$ & & $.106^{* * *}$ & $.101^{* *}$ \\
\hline & $(.007)$ & $(.026)$ & $(.020)$ & $(.018)$ & & $(.027)$ & $(.018)$ & $(.029)$ & $(.017)$ & & (.030) & $(.046)$ \\
\hline \multirow[t]{2}{*}{ Literacy } & $.076^{* * *}$ & $136^{* * *}$ & $.090^{* * *}$ & $113^{* * *}$ & & $.091^{* * *}$ & $.040^{* *}$ & .017 & $.060^{* * *}$ & & $.128^{* * *}$ & $.098^{* *}$ \\
\hline & $(.007)$ & $(.026)$ & (.023) & $(.020)$ & & $(.028)$ & $(.019)$ & $(.029)$ & $(.019)$ & & $(.028)$ & $(.048)$ \\
\hline \multirow[t]{2}{*}{ Problem solv. } & $.037^{* * *}$ & .019 & .004 & .007 & & $.046^{* *}$ & $.050^{* * *}$ & $.082^{* * *}$ & .015 & & .014 & .029 \\
\hline & $(.005)$ & $(.020)$ & $(.017)$ & $(.014)$ & & (.022) & $(.016)$ & $(.029)$ & $(.016)$ & & (.022) & $(.030)$ \\
\hline Numeracy & $.183^{* * *}$ & $.193^{* * *}$ & $.151^{* * *}$ & $182^{* * *}$ & $153^{* * *}$ & $.150^{* * *}$ & $.135^{* * *}$ & $.208^{* * *}$ & $.149^{* * *}$ & $.160^{* * *}$ & $.240^{* * *}$ & $.238^{* * *}$ \\
\hline (int. stand.) & $(.003)$ & $(.011)$ & $(.009)$ & $(.007)$ & $(.021)$ & $(.019)$ & $(.008)$ & $(.014)$ & $(.011)$ & $(.008)$ & $(.013)$ & $(.020)$ \\
\hline
\end{tabular}


Table A-3: Returns to Skills for Alternative Skill Measures: Numeracy, Literacy, and Problem Solving (continued)

\begin{tabular}{|c|c|c|c|c|c|c|c|c|c|c|c|}
\hline & Italy & Japan & Korea & Netherl. & Norway & Poland & Slovak R. & Spain & Sweden & U.K. & U.S. \\
\hline \multirow[t]{2}{*}{ Numeracy } & $.132^{* * *}$ & $.184^{* * *}$ & $.217^{* * *}$ & $.183^{* * *}$ & $.127^{* * *}$ & $.191^{* * *}$ & $.179^{* * *}$ & $.228^{* * *}$ & $.121^{* * *}$ & $.225^{* * *}$ & $.279^{* * *}$ \\
\hline & $(.016)$ & $(.014)$ & $(.014)$ & $(.011)$ & $(.007)$ & $(.017)$ & $(.019)$ & $(.017)$ & $(.009)$ & $(.013)$ & $(.017)$ \\
\hline \multirow[t]{2}{*}{ Literacy } & $.127^{* * *}$ & $.149^{* * *}$ & $.206^{* * *}$ & $.191^{* * *}$ & $.116^{* * *}$ & $.201^{* * *}$ & $.139^{* * *}$ & $.220^{* * *}$ & $.123^{* * *}$ & $.215^{* * *}$ & $.271^{* * *}$ \\
\hline & $(.016)$ & $(.015)$ & $(.015)$ & $(.012)$ & $(.008)$ & $(.017)$ & $(.019)$ & $(.016)$ & $(.008)$ & $(.013)$ & $(.016)$ \\
\hline \multirow[t]{2}{*}{ Problem solv. } & & $.119^{* * *}$ & $.153^{* * *}$ & $.171^{* * *}$ & $.110^{* * *}$ & $.135^{* * *}$ & $.135^{* * *}$ & & $.104^{* * *}$ & $.191^{* * *}$ & $.217^{* * *}$ \\
\hline & & $(.015)$ & $(.017)$ & (.012) & $(.007)$ & (.022) & $(.021)$ & & $(.007)$ & $(.013)$ & $(.015)$ \\
\hline \multirow[t]{2}{*}{ Numeracy } & $.084^{* * *}$ & $.233^{* * *}$ & $.162^{* * *}$ & $.075^{* * *}$ & $.110^{* * *}$ & $.069^{* *}$ & $.180^{* * *}$ & $.137^{* * *}$ & $.071^{* * *}$ & $.124^{* * *}$ & $.192^{* * *}$ \\
\hline & (.023) & $(.024)$ & $(.028)$ & (.023) & $(.017)$ & $(.028)$ & $(.029)$ & $(.029)$ & $(.018)$ & $(.025)$ & $(.034)$ \\
\hline \multirow[t]{2}{*}{ Literacy } & $.058^{* *}$ & $-.062^{* *}$ & $.064^{* *}$ & $.126^{* * *}$ & .019 & $.145^{* * *}$ & -.001 & $.105^{* * *}$ & $.058^{* * *}$ & $.113^{* * *}$ & $.099^{* * *}$ \\
\hline & $(.024)$ & $(.026)$ & $(.029)$ & $(.025)$ & $(.018)$ & $(.028)$ & $(.028)$ & $(.028)$ & $(.017)$ & $(.025)$ & (.032) \\
\hline \multirow[t]{2}{*}{ Numeracy } & & $.164^{* * *}$ & $.186^{* * *}$ & $.110^{* * *}$ & $.067^{* * *}$ & $.163^{* * *}$ & $.077^{* *}$ & & $.071^{* * *}$ & $109^{* * *}$ & $.175^{* * *}$ \\
\hline & & (.022) & $(.029)$ & $(.019)$ & $(.015)$ & $(.041)$ & (.030) & & $(.014)$ & $(.024)$ & $(.031)$ \\
\hline \multirow[t]{2}{*}{ Problem solv. } & & .013 & .037 & $.092^{* * *}$ & $.064^{* * *}$ & .044 & $.095^{* * *}$ & & $.056^{* * *}$ & $.116^{* * *}$ & $.097^{* * *}$ \\
\hline & & $(.020)$ & $(.026)$ & $(.018)$ & $(.013)$ & (.032) & $(.025)$ & & $(.012)$ & $(.021)$ & $(.026)$ \\
\hline \multirow[t]{2}{*}{ Numeracy } & & $.185^{* * *}$ & $.131^{* * *}$ & $.054^{* *}$ & $.059^{* * *}$ & .058 & $.099^{* * *}$ & & $.051^{* * *}$ & .047 & $.173^{* * *}$ \\
\hline & & $(.027)$ & $(.037)$ & $(.025)$ & $(.019)$ & $(.044)$ & $(.037)$ & & $(.018)$ & $(.030)$ & $(.036)$ \\
\hline \multirow[t]{2}{*}{ Literacy } & & -.033 & $.093^{* *}$ & $.105^{* * *}$ & .013 & $.180^{* * *}$ & -.040 & & $.033^{*}$ & $.098^{* * *}$ & .005 \\
\hline & & $(.029)$ & $(.040)$ & $(.030)$ & $(.020)$ & $(.043)$ & $(.040)$ & & $(.019)$ & $(.029)$ & $(.039)$ \\
\hline \multirow[t]{2}{*}{ Problem solv. } & & .020 & .008 & $.049^{* *}$ & $.060^{* * *}$ & -.013 & $.106^{* * *}$ & & $.048^{* * *}$ & $.085^{* * *}$ & $.095^{* * *}$ \\
\hline & & $(.021)$ & $(.029)$ & (.022) & $(.014)$ & $(.036)$ & $(.029)$ & & $(.013)$ & (.023) & $(.039)$ \\
\hline Numeracy & $.138^{* * *}$ & $.223^{* * *}$ & $.249^{* * *}$ & $.195^{* * *}$ & $.124^{* * *}$ & $.203^{* * *}$ & $.197^{* * *}$ & $.224^{* * *}$ & $.112^{* * *}$ & $.222^{* * *}$ & $.262^{* * *}$ \\
\hline (int. stand.) & $(.017)$ & $(.016)$ & $(.016)$ & $(.012)$ & $(.007)$ & $(.018)$ & $(.021)$ & $(.017)$ & $(.008)$ & $(.013)$ & $(.016)$ \\
\hline
\end{tabular}

Notes: Horizontal lines divide separately estimated models. First row replicates baseline model from Table 2 . Least squares regressions weighted by sampling weights. Dependent variable: log gross hourly wage. Sample: full-time employees aged 35-54 (Canada includes part-time employees). All regressions control for gender and a quadratic polynomial in actual work experience. Test scores standardized to std. dev. 1 within each country, except for last specification at the bottom where numeracy score is standardized to std. dev. 1 in the entire international sample. All models with problem solving do not include Cyprus, France, Italy, and Spain, where problem-solving skills were not tested, as well as individuals who opted out of the problem-solving test. Pooled specification includes country fixed effects and gives same weight to each country. Robust standard errors in parentheses. Data source: PIAAC. 
Table A-4: Returns to Skills in Alternative Subgroups

\begin{tabular}{|c|c|c|c|c|c|c|c|c|c|c|c|c|}
\hline Subsample & Pooled & Austria & Belgium & Canada & Cyprus & Czech R. & Denmark & Estonia & Finland & France & Germany & Ireland \\
\hline \multirow[t]{2}{*}{ Baseline } & $.178^{* * *}$ & $.179^{* * *}$ & $.149^{* * *}$ & $.193^{* * *}$ & $.138^{* * *}$ & $.124^{* * *}$ & $.137^{* * *}$ & $.179^{* * *}$ & $.142^{* * *}$ & $.174^{* * *}$ & $.235^{* * *}$ & $.241^{* * *}$ \\
\hline & (.003) & $(.010)$ & $(.009)$ & $(.008)$ & $(.019)$ & $(.015)$ & $(.008)$ & $(.012)$ & $(.010)$ & $(.008)$ & $(.013)$ & $(.020)$ \\
\hline \multirow[t]{2}{*}{$\overline{\text { Males }}$} & $.178^{* * *}$ & $.164^{* * *}$ & $.150^{* * *}$ & $.191^{* * *}$ & $.148^{* * *}$ & $.089^{* * *}$ & $.131^{* * *}$ & $.177^{* * *}$ & $.130^{* * *}$ & $.172^{* * *}$ & $.241^{* * *}$ & $241^{* * *}$ \\
\hline & $(.004)$ & $(.011)$ & $(.011)$ & $(.010)$ & $(.027)$ & $(.025)$ & (.012) & $(.019)$ & $(.017)$ & $(.011)$ & $(.016)$ & $(.027)$ \\
\hline \multirow[t]{2}{*}{$\Delta$ Females } & -.002 & $.045^{* *}$ & -.004 & .005 & -.022 & $.065^{* *}$ & .012 & .004 & .023 & .004 & -.024 & -.002 \\
\hline & $(.006)$ & (.022) & $(.018)$ & $(.015)$ & $(.037)$ & $(.030)$ & $(.016)$ & $(.024)$ & $(.020)$ & $(.017)$ & $(.021)$ & (.039) \\
\hline \multirow[t]{2}{*}{ Low parent ed. } & $.148^{* * *}$ & $.157^{* * *}$ & $.141^{* * *}$ & $188^{* * *}$ & $104^{* * *}$ & $.089^{* * *}$ & $.121^{* * *}$ & $.097^{* * *}$ & $.170^{* * *}$ & $.143^{* * *}$ & $.232^{* * *}$ & $200^{* * *}$ \\
\hline & $(.005)$ & $(.017)$ & $(.014)$ & $(.015)$ & (.023) & $(.029)$ & $(.013)$ & $(.024)$ & $(.012)$ & (.012) & $(.046)$ & $(.034)$ \\
\hline \multirow[t]{2}{*}{$\Delta$ Medium par. ed. } & $.014^{* *}$ & -.005 & -.008 & -.014 & .070 & .019 & .014 & $.058^{*}$ & $-.044^{* *}$ & .001 & .004 & .039 \\
\hline & $(.007)$ & $(.023)$ & (.022) & $(.020)$ & $(.043)$ & $(.035)$ & $(.019)$ & (.032) & $(.018)$ & $(.021)$ & $(.020)$ & $(.049)$ \\
\hline \multirow[t]{2}{*}{$\Delta$ High parent ed. } & $.033^{* * *}$ & $.068^{* *}$ & -.013 & .001 & $.129^{*}$ & .071 & .005 & $.129^{* * *}$ & $-.077^{*}$ & $.108^{* * *}$ & .066 & -.010 \\
\hline & $(.009)$ & $(.034)$ & $(.026)$ & $(.021)$ & (.072) & $(.061)$ & (.022) & $(.035)$ & $(.045)$ & $(.034)$ & $(.053)$ & $(.049)$ \\
\hline \multirow[t]{2}{*}{ Private sector } & $.183^{* * *}$ & $.180^{* * *}$ & $.152^{* * *}$ & $190^{* * *}$ & $.116^{* * *}$ & $.112^{* * *}$ & $.151^{* * *}$ & $.185^{* * *}$ & $.139^{* * *}$ & $.188^{* * *}$ & $.249^{* * *}$ & $270^{* * *}$ \\
\hline & $(.004)$ & (.012) & $(.011)$ & $(.010)$ & $(.024)$ & $(.018)$ & $(.011)$ & $(.015)$ & $(.016)$ & $(.010)$ & $(.016)$ & $(.023)$ \\
\hline \multirow[t]{2}{*}{$\Delta$ Public sector } & $-.036^{* * *}$ & -.012 & -.002 & $-.042^{* * *}$ & .037 & .043 & $-.034^{* *}$ & -.009 & .010 & $-.038^{* *}$ & $-.080^{* * *}$ & $-.115^{* * *}$ \\
\hline & $(.006)$ & $(.024)$ & $(.019)$ & $(.016)$ & $(.039)$ & $(.036)$ & $(.016)$ & $(.025)$ & $(.019)$ & $(.018)$ & (.028) & $(.040)$ \\
\hline \multirow[t]{2}{*}{ Natives } & $.180^{* * *}$ & $.177^{* * *}$ & $.149^{* * *}$ & $.196^{* * *}$ & $132^{* * *}$ & $.126^{* * *}$ & $137^{* * *}$ & $.177^{* * *}$ & $.155^{* * *}$ & $.178^{* * *}$ & $.239^{* * *}$ & $.258^{* * *}$ \\
\hline & (.003) & (.013) & $(.010)$ & $(.009)$ & $(.020)$ & $(.017)$ & (.009) & $(.013)$ & $(.009)$ & $(.009)$ & $(.015)$ & (.023) \\
\hline \multirow[t]{2}{*}{$\Delta$ Migrants } & $-.022^{* *}$ & -.010 & -.020 & -.013 & .061 & -.033 & -.020 & -.028 & $-.103^{* *}$ & -.030 & -.048 & $-.086^{* *}$ \\
\hline & $(.008)$ & $(.024)$ & (.029) & $(.017)$ & $(.064)$ & $(.044)$ & $(.021)$ & $(.044)$ & $(.042)$ & (.029) & (.039) & $(.043)$ \\
\hline \multirow[t]{2}{*}{ Part-time } & $.122^{* * *}$ & $123^{* * *}$ & $182^{* * *}$ & & $.132^{*}$ & -.005 & .027 & $.096^{*}$ & $.218^{* * *}$ & $.159^{* * *}$ & $.122^{* * *}$ & $.151^{* * *}$ \\
\hline & $(.008)$ & $(.019)$ & $(.024)$ & & $(.068)$ & (.103) & (.039) & $(.053)$ & $(.058)$ & $(.023)$ & $(.030)$ & $(.031)$ \\
\hline \multirow[t]{2}{*}{$\Delta$ Full-time } & $.057^{* * *}$ & $.056^{* * *}$ & -.034 & & .006 & .129 & $.110^{* * *}$ & .083 & -.077 & .015 & $.113^{* * *}$ & $.091^{* *}$ \\
\hline & $(.009)$ & $(.021)$ & $(.025)$ & & $(.070)$ & $(.104)$ & $(.040)$ & $(.054)$ & $(.059)$ & $(.025)$ & (.032) & $(.036)$ \\
\hline
\end{tabular}

${ }^{*} \mathrm{p}<0.10,{ }^{* *} \mathrm{p}<0.05,{ }^{* * *} \mathrm{p}<0.01$ 
Table A-4: Returns to Skills in Alternative Subgroups (continued)

\begin{tabular}{|c|c|c|c|c|c|c|c|c|c|c|c|}
\hline$\overline{\text { Subsample }}$ & Italy & Japan & Korea & Netherl. & Norway & Poland & Slovak R. & Spain & Sweden & U.K. & U.S. \\
\hline \multirow[t]{2}{*}{ Baseline } & $.132^{* * *}$ & $.184^{* * *}$ & $217^{* * *}$ & $.183^{* * *}$ & $.127^{* * *}$ & $.191^{* * *}$ & $.179^{* * *}$ & $.228^{* * *}$ & $.121^{* * *}$ & $.225^{* * *}$ & $.279^{* * *}$ \\
\hline & $(.016)$ & $(.014)$ & $(.014)$ & $(.011)$ & $(.007)$ & $(.017)$ & $(.019)$ & $(.017)$ & $(.009)$ & $(.013)$ & $(.017)$ \\
\hline \multirow[t]{2}{*}{ Males } & $.124^{* * *}$ & $.195^{* * *}$ & $.240^{* * *}$ & $.179^{* * *}$ & $.125^{* * *}$ & $.197^{* * *}$ & $.178^{* * *}$ & $.220^{* * *}$ & $.124^{* * *}$ & $.231^{* * *}$ & $.284^{* * *}$ \\
\hline & (.022) & $(.017)$ & $(.018)$ & $(.013)$ & $(.010)$ & $(.021)$ & $(.029)$ & (.023) & $(.013)$ & $(.017)$ & $(.028)$ \\
\hline \multirow[t]{2}{*}{$\Delta$ Females } & .026 & -.032 & $-.062^{* *}$ & .012 & .005 & -.022 & -.001 & .022 & -.006 & -.021 & -.019 \\
\hline & $(.030)$ & $(.028)$ & $(.030)$ & $(.025)$ & $(.014)$ & $(.034)$ & $(.038)$ & (.033) & $(.017)$ & $(.025)$ & $(.033)$ \\
\hline \multirow[t]{2}{*}{ Low parent ed. } & $.116^{* * *}$ & $.149^{* * *}$ & $.176^{* * *}$ & $.166^{* * *}$ & $.122^{* * *}$ & $.082^{* * *}$ & $.124^{* * *}$ & $.216^{* * *}$ & $.121^{* * *}$ & $.191^{* * *}$ & $.266^{* * *}$ \\
\hline & $(.018)$ & $(.026)$ & $(.018)$ & $(.014)$ & $(.011)$ & $(.025)$ & $(.029)$ & $(.017)$ & $(.011)$ & (.032) & $(.045)$ \\
\hline \multirow[t]{2}{*}{$\Delta$ Medium par. ed. } & .011 & .032 & .037 & .007 & -.000 & $.128^{* * *}$ & .031 & -.092 & .011 & .015 & -.043 \\
\hline & $(.035)$ & $(.034)$ & $(.038)$ & $(.030)$ & $(.017)$ & $(.034)$ & $(.039)$ & (.062) & $(.020)$ & $(.040)$ & $(.054)$ \\
\hline \multirow[t]{2}{*}{$\Delta$ High parent ed. } & -.154 & .025 & $.089^{* *}$ & .050 & -.026 & $.163^{* * *}$ & -.016 & .080 & -.014 & -.002 & -.031 \\
\hline & $(.126)$ & $(.040)$ & $(.044)$ & (.032) & $(.018)$ & (.062) & $(.083)$ & $(.060)$ & $(.021)$ & $(.045)$ & $(.054)$ \\
\hline \multirow[t]{2}{*}{ Private sector } & $.148^{* * *}$ & $180^{* * *}$ & $.205^{* * *}$ & $.187^{* * *}$ & $.143^{* * *}$ & $.193^{* * *}$ & $.174^{* * *}$ & $.199^{* * *}$ & $.139^{* * *}$ & $.246^{* * *}$ & $.288^{* * *}$ \\
\hline & $(.018)$ & $(.015)$ & $(.017)$ & $(.014)$ & (.009) & (.023) & $(.026)$ & $(.021)$ & $(.010)$ & $(.016)$ & $(.021)$ \\
\hline \multirow[t]{2}{*}{$\Delta$ Public sector } & $-.080^{* *}$ & -.038 & $-.093^{* * *}$ & -.025 & $-.041^{* * *}$ & -.030 & .012 & -.008 & $-.054^{* * *}$ & $-.084^{* * *}$ & -.037 \\
\hline & (.033) & (.032) & $(.036)$ & $(.024)$ & $(.015)$ & $(.034)$ & $(.036)$ & $(.033)$ & $(.019)$ & (.025) & $(.040)$ \\
\hline \multirow[t]{2}{*}{ Natives } & $.123^{* * *}$ & & & $.176^{* * *}$ & $.119^{* * *}$ & & & $.233^{* * *}$ & $.128^{* * *}$ & $.224^{* * *}$ & $270^{* * *}$ \\
\hline & $(.017)$ & & & (.012) & $(.009)$ & & & $(.016)$ & $(.009)$ & $(.014)$ & $(.021)$ \\
\hline \multirow[t]{2}{*}{$\Delta$ Migrants } & .007 & & & -.016 & .008 & & & $-.123^{*}$ & -.028 & .053 & .032 \\
\hline & $(.059)$ & & & $(.034)$ & $(.016)$ & & & (.072) & (.022) & $(.043)$ & $(.039)$ \\
\hline \multirow[t]{2}{*}{ Part-time } & $.155^{* * *}$ & $.067^{*}$ & .109 & $.097^{* * *}$ & $.113^{* * *}$ & -.013 & .044 & $.178^{* * *}$ & .021 & $.166^{* * *}$ & $.152^{* *}$ \\
\hline & $(.031)$ & $(.036)$ & $(.078)$ & $(.019)$ & $(.026)$ & $(.087)$ & $(.101)$ & $(.041)$ & $(.036)$ & $(.030)$ & $(.059)$ \\
\hline \multirow[t]{2}{*}{$\Delta$ Full-time } & -.023 & $117^{* * *}$ & .108 & $.086^{* * *}$ & .013 & $.203^{* *}$ & .135 & .050 & $.099^{* * *}$ & $.059^{*}$ & $.127^{* *}$ \\
\hline & $(.035)$ & $(.039)$ & $(.080)$ & (.022) & $(.027)$ & $(.089)$ & (.102) & $(.044)$ & $(.037)$ & (.032) & (.062) \\
\hline
\end{tabular}

Notes: Horizontal lines divide separately estimated models. Each row without a $\Delta$ reports the coefficient on numeracy for the respective subgroup. Each row with a $\Delta$ reports the marginal difference for the identified subgroup, estimated with an interaction term between numeracy and the specified subgroup indicator. (The total gradient for this subgroup is the sum of the coefficient of the top group and this marginal effect.) Least squares regressions weighted by sampling weights. Dependent variable: log gross hourly wage. Sample: full-time employees aged 35-54 (Canada includes part-time employees), except for bottom panel which additionally includes part-time employees. All regressions control for gender, a quadratic polynomial in actual work experience, the respective subgroup indicator, and interactions of the covariates with the respective subgroup indicator. Baseline: replicates Table 2. Parental education: low = neither parent attained upper secondary education; medium $=$ at least one parent attained upper secondary education; high $=$ at least one parent attained tertiary education. Migrants: $1=$ workers born abroad (with at least one parent also born abroad). Full-time: 1 = working more than 30 hours per week. Numeracy score standardized to std. dev. 1 within each country. Pooled specification includes country fixed effects and gives same weight to each country. Robust standard errors in parentheses. Data source: PIAAC. 
Table A-5: Returns to Skills with Alternative Sets of Control Variables

\begin{tabular}{|c|c|c|c|c|c|c|c|c|c|c|c|c|}
\hline Controls & Pooled & Austria & Belgium & Canada & Cyprus & Czech R. & Denmark & Estonia & Finland & France & Germany & Ireland \\
\hline \multirow[t]{2}{*}{ Baseline } & $.178^{* * *}$ & $.179^{* * *}$ & $.149^{* * *}$ & $.193^{* * *}$ & $.138^{* * *}$ & $.124^{* * *}$ & $.137^{* * *}$ & $.179^{* * *}$ & $.142^{* * *}$ & $.174^{* * *}$ & $.235^{* * *}$ & $.241^{* * *}$ \\
\hline & (.003) & $(.010)$ & $(.009)$ & $(.008)$ & $(.019)$ & $(.015)$ & $(.008)$ & (.012) & $(.010)$ & $(.008)$ & $(.013)$ & $(.020)$ \\
\hline Parental & $.162^{* * *}$ & $.164^{* * *}$ & $.135^{* * *}$ & $.182^{* * *}$ & $.127^{* * *}$ & $.115^{* * *}$ & $.129^{* * *}$ & $.156^{* * *}$ & $.139^{* * *}$ & $.155^{* * *}$ & $.225^{* * *}$ & $.220^{* * *}$ \\
\hline education [3] & $(.003)$ & $(.011)$ & $(.010)$ & $(.008)$ & $(.019)$ & $(.016)$ & $(.008)$ & $(.013)$ & $(.011)$ & $(.010)$ & $(.014)$ & (.022) \\
\hline \multirow[t]{2}{*}{ Migrant [1] } & $.175^{* * *}$ & $.172^{* * *}$ & $147^{* * *}$ & $.192^{* * *}$ & $.137^{* * *}$ & $.123^{* * *}$ & $.134^{* * *}$ & $175^{* * *}$ & $.140^{* * *}$ & $.175^{* * *}$ & $.231^{* * *}$ & $.242^{* * *}$ \\
\hline & $(.003)$ & $(.011)$ & $(.009)$ & $(.008)$ & $(.019)$ & $(.016)$ & $(.008)$ & (.012) & $(.010)$ & $(.009)$ & $(.014)$ & $(.020)$ \\
\hline Potential & $.169^{* * *}$ & $.175^{* * *}$ & $.150^{* * *}$ & $.191^{* * *}$ & $.136^{* * *}$ & $.114^{* * *}$ & $.128^{* * *}$ & $.153^{* * *}$ & $.134^{* * *}$ & $.167^{* * *}$ & $.224^{* * *}$ & $.238^{* * *}$ \\
\hline experience [2] & $(.003)$ & $(.010)$ & $(.009)$ & $(.008)$ & $(.019)$ & $(.017)$ & $(.008)$ & (.012) & $(.010)$ & $(.009)$ & $(.014)$ & $(.021)$ \\
\hline \multirow[t]{2}{*}{ ISCO $[10]$} & $.096^{* * *}$ & $.095^{* * *}$ & $.088^{* * *}$ & $.109^{* * *}$ & $.080^{* * *}$ & $.055^{* * *}$ & $.082^{* * *}$ & $.097^{* * *}$ & $.054^{* * *}$ & $.086^{* * *}$ & $.125^{* * *}$ & $.161^{* * *}$ \\
\hline & $(.003)$ & $(.010)$ & $(.010)$ & $(.008)$ & $(.017)$ & $(.016)$ & $(.008)$ & $(.012)$ & $(.010)$ & $(.008)$ & $(.013)$ & (.022) \\
\hline \multirow[t]{2}{*}{ ISIC [22] } & $.150^{* * *}$ & $.150^{* * *}$ & $.133^{* * *}$ & $.145^{* * *}$ & $.096^{* * *}$ & $.107^{* * *}$ & $.121^{* * *}$ & $.160^{* * *}$ & $.120^{* * *}$ & $.154^{* * *}$ & $.200^{* * *}$ & $.194^{* * *}$ \\
\hline & $(.003)$ & $(.010)$ & $(.009)$ & $(.008)$ & $(.018)$ & $(.015)$ & $(.008)$ & $(.013)$ & $(.010)$ & $(.008)$ & $(.013)$ & (.022) \\
\hline \multirow{2}{*}{$\begin{array}{l}\text { Educational } \\
\text { attainment [6] }\end{array}$} & $.103^{* * *}$ & $.114^{* * *}$ & $.085^{* * *}$ & $.127^{* * *}$ & $.062^{* * *}$ & $.088^{* * *}$ & $.084^{* * *}$ & $.118^{* * *}$ & $.075^{* * *}$ & $.094^{* * *}$ & $.144^{* * *}$ & $.134^{* * *}$ \\
\hline & $(.003)$ & $(.011)$ & $(.010)$ & $(.009)$ & $(.019)$ & $(.020)$ & $(.008)$ & $(.014)$ & $(.011)$ & $(.009)$ & $(.014)$ & $(.024)$ \\
\hline \multicolumn{2}{|l|}{ 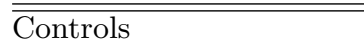 } & 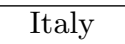 & $\overline{~ J a p a n ~}$ & Korea & Netherl. & Norway & Poland & Slovak R. & Spain & Sweden & "U.K. & U.S. \\
\hline \multirow{2}{*}{\multicolumn{2}{|c|}{ Baseline }} & $.132^{* * *}$ & $.184^{* * *}$ & $.217^{* * *}$ & $.183^{* * *}$ & $.127^{* * *}$ & $.191^{* * *}$ & $.179^{* * *}$ & $.228^{* * *}$ & $.121^{* * *}$ & $.225^{* * *}$ & $.279^{* * *}$ \\
\hline & & $(.016)$ & $(.014)$ & $(.014)$ & $(.011)$ & $(.007)$ & $(.017)$ & $(.019)$ & $(.017)$ & $(.009)$ & $(.013)$ & $(.017)$ \\
\hline \multirow{2}{*}{\multicolumn{2}{|c|}{$\begin{array}{l}\text { Parental } \\
\text { education [3] }\end{array}$}} & $.112^{* * *}$ & $.170^{* * *}$ & $.195^{* * *}$ & $.176^{* * *}$ & $.114^{* * *}$ & $.170^{* * *}$ & $.140^{* * *}$ & $.210^{* * *}$ & $.120^{* * *}$ & $.198^{* * *}$ & $.236^{* * *}$ \\
\hline & & $(.017)$ & $(.014)$ & $(.015)$ & $(.012)$ & $(.008)$ & $(.017)$ & $(.019)$ & $(.017)$ & $(.008)$ & $(.016)$ & $(.019)$ \\
\hline \multirow{2}{*}{\multicolumn{2}{|c|}{ Migrant [1] }} & $.123^{* * *}$ & $.184^{* * *}$ & $.217^{* * *}$ & $.175^{* * *}$ & $.122^{* * *}$ & $.191^{* * *}$ & $179^{* * *}$ & $.216^{* * *}$ & $.119^{* * *}$ & $.229^{* * *}$ & $.278^{* * *}$ \\
\hline & & $(.017)$ & $(.014)$ & $(.014)$ & $(.012)$ & $(.008)$ & $(.017)$ & $(.019)$ & $(.018)$ & $(.009)$ & $(.013)$ & $(.018)$ \\
\hline \multirow{2}{*}{\multicolumn{2}{|c|}{$\begin{array}{l}\text { Potential } \\
\text { experience }[2]\end{array}$}} & $.129^{* * *}$ & $.184^{* * *}$ & $.198^{* * *}$ & $179^{* * *}$ & $.125^{* * *}$ & $.173^{* * *}$ & $.158^{* * *}$ & $212^{* * *}$ & $.124^{* * *}$ & $.209^{* * *}$ & $.269^{* * *}$ \\
\hline & & $(.017)$ & $(.014)$ & $(.016)$ & $(.012)$ & $(.008)$ & $(.017)$ & $(.019)$ & $(.018)$ & $(.009)$ & $(.014)$ & $(.018)$ \\
\hline \multirow[t]{2}{*}{ ISCO $[10]$} & & $.066^{* * *}$ & $.118^{* * *}$ & $.113^{* * *}$ & $.100^{* * *}$ & $.075^{* * *}$ & $.088^{* * *}$ & $.099^{* * *}$ & $.115^{* * *}$ & $.061^{* * *}$ & $.129^{* * *}$ & $.158^{* * *}$ \\
\hline & & $(.016)$ & $(.014)$ & $(.015)$ & (.012) & $(.008)$ & $(.015)$ & $(.018)$ & $(.017)$ & $(.008)$ & $(.013)$ & $(.018)$ \\
\hline \multirow[t]{2}{*}{ ISIC [22] } & & $.100^{* * *}$ & $.158^{* * *}$ & $.170^{* * *}$ & $.158^{* * *}$ & $.106^{* * *}$ & $.155^{* * *}$ & $.152^{* * *}$ & $.152^{* * *}$ & $.102^{* * *}$ & $.166^{* * *}$ & $.234^{* * *}$ \\
\hline & & $(.016)$ & $(.014)$ & $(.015)$ & $(.012)$ & $(.007)$ & $(.017)$ & $(.017)$ & $(.017)$ & $(.008)$ & $(.013)$ & $(.017)$ \\
\hline \multirow{2}{*}{$\begin{array}{l}\text { Educational } \\
\text { attainment [6] }\end{array}$} & & $.071^{* * *}$ & $.111^{* * *}$ & $.092^{* * *}$ & $.105^{* * *}$ & $.073^{* * *}$ & $.083^{* * *}$ & $.101^{* * *}$ & $.098^{* * *}$ & $.086^{* * *}$ & $.158^{* * *}$ & $.149^{* * *}$ \\
\hline & & $(.016)$ & $(.015)$ & $(.015)$ & $(.012)$ & $(.008)$ & $(.015)$ & $(.018)$ & $(.018)$ & $(.010)$ & $(.015)$ & $(.020)$ \\
\hline
\end{tabular}

Notes: Each cell reports the coefficient on numeracy skills from a separate regression. Least squares regressions weighted by sampling weights. Dependent variable: log gross hourly wage. Sample: full-time employees aged 35-54 (Canada includes part-time employees). All regressions control for gender, a quadratic polynomial in actual work experience (unless otherwise noted), and respective additional control variables as indicated in first column. Numbers in square brackets report the number of dummy variables included for the respective measure. Baseline: replicates Table 2. Parental education: adds controls for low/medium/high parental education (see Table A-4). Migrant: adds control for indicator variable for first-generation migrants. Potential experience: replaces the quadratic polynomial in actual work experience by a quadratic polynomial in potential work experience (age minus years of schooling minus 6). ISCO: adds controls for one-digit occupation categories. ISIC: adds controls for one-digit industry categories. Educational attainment: adds controls for school attainment, measured by 6 ISCED dummies. Numeracy score standardized to std. dev. 1 within each country. Pooled specification includes country fixed effects and gives same weight to each country. Robust standard errors in parentheses. Data source: PIAAC. 
Table A-6: Extended Model with Part-Time Workers and Additional Control Variables

\begin{tabular}{|c|c|c|c|c|c|c|c|c|c|c|c|c|}
\hline & Pooled & Austria & Belgium & Canada & Cyprus & Czech R. & Denmark & Estonia & Finland & France & Germany & Ireland \\
\hline \multirow[t]{2}{*}{ Numeracy } & $.150^{* * *}$ & $.145^{* * *}$ & $.137^{* * *}$ & $.179^{* * *}$ & $.113^{* * *}$ & $.110^{* * *}$ & $.112^{* * *}$ & $.150^{* * *}$ & $.137^{* * *}$ & $.157^{* * *}$ & $.188^{* * *}$ & $.194^{* * *}$ \\
\hline & (.003) & $(.010)$ & $(.009)$ & $(.008)$ & $(.019)$ & $(.017)$ & $(.009)$ & $(.013)$ & $(.010)$ & $(.010)$ & $(.015)$ & $(.019)$ \\
\hline \multirow[t]{2}{*}{ Experience } & $.022^{* * *}$ & .006 & $.027^{* * *}$ & $.021^{* * *}$ & $.020^{* *}$ & $.017^{* *}$ & .004 & $.030^{* * *}$ & $.016^{* * *}$ & $.022^{* * *}$ & .004 & $.033^{* * *}$ \\
\hline & $(.001)$ & $(.007)$ & $(.006)$ & $(.004)$ & $(.010)$ & $(.008)$ & $(.004)$ & $(.009)$ & $(.005)$ & $(.005)$ & $(.007)$ & $(.009)$ \\
\hline \multirow[t]{2}{*}{ Experience $^{2}$} & $-.036^{* * *}$ & -.007 & $-.041^{* * *}$ & $-.031^{* * *}$ & -.027 & $-.039^{* *}$ & -.005 & $-.075^{* * *}$ & $-.031^{* * *}$ & $-.030^{* * *}$ & .003 & $-.051^{* *}$ \\
\hline & (.003) & $(.013)$ & (.012) & (.008) & $(.021)$ & $(.020)$ & $(.008)$ & (.020) & (.012) & $(.010)$ & $(.016)$ & $(.020)$ \\
\hline \multirow[t]{2}{*}{ Female } & $-.157^{* * *}$ & $-.111^{* * *}$ & -.026 & $-.112^{* * *}$ & $-.236^{* * *}$ & $-199^{* * *}$ & $-.089^{* * *}$ & $-.381^{* * *}$ & $-.157^{* * *}$ & $-.098^{* * *}$ & $-.096^{* * *}$ & .005 \\
\hline & $(.005)$ & (.023) & $(.017)$ & $(.015)$ & $(.034)$ & $(.034)$ & $(.014)$ & $(.025)$ & $(.016)$ & $(.018)$ & $(.027)$ & $(.031)$ \\
\hline \multirow[t]{2}{*}{ Med. par. ed. } & $.079^{* * *}$ & $.081^{* * *}$ & $.032^{*}$ & $.044^{* *}$ & $.172^{* * *}$ & .048 & .009 & $.118^{* * *}$ & .021 & $.047^{* * *}$ & .013 & $.078^{* *}$ \\
\hline & $(.006)$ & $(.021)$ & $(.019)$ & $(.019)$ & $(.042)$ & $(.046)$ & $(.016)$ & $(.029)$ & $(.017)$ & $(.018)$ & $(.040)$ & (.034) \\
\hline \multirow[t]{2}{*}{ High par. ed. } & $.174^{* * *}$ & $.165^{* * *}$ & $.145^{* * *}$ & $.102^{* * *}$ & $.307^{* * *}$ & $.156^{* *}$ & $.066^{* * *}$ & $.206^{* * *}$ & $.106^{* * *}$ & $.160^{* * *}$ & $.089^{*}$ & $.230^{* * *}$ \\
\hline & $(.007)$ & $(.030)$ & (.023) & $(.020)$ & $(.059)$ & $(.064)$ & $(.019)$ & $(.034)$ & $(.027)$ & $(.028)$ & $(.043)$ & $(.039)$ \\
\hline \multirow[t]{2}{*}{ Migrant } & $-.052^{* * *}$ & $-.055^{*}$ & -.049 & -.019 & $-.330^{* * *}$ & -.074 & $-.083^{* * *}$ & $-.183^{* * *}$ & -.051 & .020 & -.063 & $-.131^{* * *}$ \\
\hline & (.009) & (.032) & $(.036)$ & $(.019)$ & (.063) & $(.109)$ & (.021) & (.037) & $(.048)$ & (.031) & $(.040)$ & $(.041)$ \\
\hline \multirow[t]{2}{*}{ Full-time } & $-.031^{* * *}$ & $.078^{* * *}$ & $-.066^{* * *}$ & & $-.347^{* * *}$ & -.076 & $-.066^{* *}$ & $-.142^{* *}$ & .045 & $-.069^{* *}$ & $.157^{* * *}$ & $.069^{*}$ \\
\hline & (.009) & $(.024)$ & (.025) & & $(.074)$ & (.099) & (.032) & $(.063)$ & $(.046)$ & $(.030)$ & $(.034)$ & $(.038)$ \\
\hline $\mathrm{R}^{2}$ & .206 & .247 & .232 & .233 & .213 & .205 & .168 & .265 & .258 & .248 & .239 & .247 \\
\hline \multirow[t]{2}{*}{ Observations } & 37935 & 1568 & 1431 & 7331 & 1024 & 1071 & 2045 & 1779 & 1521 & 1668 & 1583 & 1340 \\
\hline & & Italy & Japan & Korea & Netherl. & Norway & Poland & Slovak R. & Spain & Sweden & U.K. & U.S. \\
\hline \multirow[t]{2}{*}{ Numeracy } & & $.104^{* * *}$ & $.155^{* * *}$ & $.180^{* * *}$ & $.144^{* * *}$ & $.111^{* * *}$ & $.149^{* * *}$ & $.133^{* * *}$ & $.197^{* * *}$ & $.106^{* * *}$ & $.185^{* * *}$ & $.229^{* * *}$ \\
\hline & & $(.015)$ & $(.013)$ & $(.016)$ & $(.011)$ & $(.008)$ & $(.019)$ & $(.019)$ & $(.017)$ & $(.009)$ & $(.016)$ & $(.019)$ \\
\hline \multirow[t]{2}{*}{ Experience } & & $.016^{* *}$ & $.017^{* * *}$ & $.034^{* * *}$ & $.024^{* * *}$ & $.020^{* * *}$ & $.044^{* * *}$ & .015 & $.020^{* * *}$ & $.017^{* * *}$ & $.014^{*}$ & .002 \\
\hline & & $(.006)$ & $(.006)$ & $(.006)$ & $(.006)$ & $(.005)$ & $(.008)$ & $(.011)$ & $(.007)$ & $(.005)$ & $(.007)$ & $(.006)$ \\
\hline \multirow[t]{2}{*}{ Experience $^{2}$} & & -.012 & -.004 & $-.060^{* * *}$ & $-.041^{* * *}$ & $-.041^{* * *}$ & $-.086^{* * *}$ & -.029 & $-.029^{*}$ & $-.034^{* * *}$ & -.022 & .002 \\
\hline & & $(.016)$ & $(.016)$ & $(.018)$ & $(.013)$ & $(.010)$ & $(.020)$ & $(.025)$ & $(.016)$ & $(.010)$ & $(.016)$ & $(.012)$ \\
\hline \multirow[t]{2}{*}{ Female } & & $-.101^{* * *}$ & $-.351^{* * *}$ & $-.427^{* * *}$ & .002 & $-.118^{* * *}$ & $-.100^{* * *}$ & $-.247^{* * *}$ & $-.055^{* *}$ & $-.088^{* * *}$ & $-.101^{* * *}$ & $-.176^{* * *}$ \\
\hline & & (.026) & (.029) & (.030) & (.023) & $(.014)$ & $(.034)$ & (.029) & $(.026)$ & $(.014)$ & (.030) & (.031) \\
\hline \multirow[t]{2}{*}{ Med. par. ed. } & & $.145^{* * *}$ & $.136^{* * *}$ & $.151^{* * *}$ & $.074^{* * *}$ & $.042^{* *}$ & $.148^{* * *}$ & $.141^{* * *}$ & $.208^{* * *}$ & .030 & $.056^{*}$ & $.189^{* * *}$ \\
\hline & & $(.030)$ & (.028) & $(.035)$ & (.022) & $(.017)$ & $(.036)$ & $(.035)$ & $(.042)$ & $(.018)$ & $(.031)$ & $(.049)$ \\
\hline \multirow[t]{2}{*}{ High par. ed. } & & $.397^{* * *}$ & $237^{* * *}$ & $.226^{* * *}$ & $.155^{* * *}$ & $.080^{* * *}$ & $408^{* * *}$ & $.468^{* * *}$ & $.165^{* * *}$ & $.049^{* * *}$ & $.199^{* * *}$ & $.298^{* * *}$ \\
\hline & & $(.096)$ & $(.034)$ & $(.045)$ & $(.026)$ & $(.019)$ & $(.059)$ & $(.063)$ & $(.042)$ & $(.017)$ & $(.041)$ & (.053) \\
\hline \multirow[t]{2}{*}{ Migrant } & & $-.225^{* * *}$ & & & -.057 & $-.040^{*}$ & & & $-.115^{* *}$ & -.011 & .030 & .004 \\
\hline & & $(.044)$ & & & $(.037)$ & (.023) & & & $(.050)$ & $(.021)$ & $(.047)$ & $(.048)$ \\
\hline \multirow[t]{2}{*}{ Full-time } & & $-.210^{* * *}$ & $.158^{* * *}$ & $-.769^{* * *}$ & $116^{* * *}$ & .022 & $-.458^{* * *}$ & -.108 & $-.080^{*}$ & .013 & $215^{* * *}$ & $286^{* * *}$ \\
\hline & & (.038) & $(.040)$ & (.069) & $(.025)$ & $(.025)$ & $(.083)$ & $(.117)$ & $(.043)$ & $(.035)$ & $(.040)$ & $(.031)$ \\
\hline $\mathrm{R}^{2}$ & & .235 & .386 & .358 & .229 & .232 & .267 & .207 & .236 & .212 & .272 & .330 \\
\hline Observations & & 1207 & 1510 & 1608 & 1510 & 1700 & 859 & 1261 & 1335 & 1355 & 1990 & 1227 \\
\hline
\end{tabular}

Notes: Least squares regressions weighted by sampling weights. Dependent variable: log gross hourly wage. Sample: employees aged $35-54$. Numeracy score standardized to std. dev. 1 within each country. Experience ${ }^{2}$ divided by 1000 . See Table A-4 for variable definitions of parental education categories, migrant, and full-time work status. Pooled specification includes country fixed effects and gives same weight to each country; $\mathrm{R}^{2}$ refers to within-country $\mathrm{R}^{2}$. Robust standard errors in parentheses. Data source: PIAAC. 
Table A-7: Returns to Skills for Alternative Earnings Measures

\begin{tabular}{|c|c|c|c|c|c|c|c|c|c|c|c|c|}
\hline Log wage & Pooled & Austria $^{\dagger}$ & Belgium & Canada $^{\dagger}$ & Cyprus & Czech R. & Denmark & Estonia & Finland & France & Germany & Ireland \\
\hline \multirow[t]{2}{*}{ Hourly (baseline) } & $.170^{* * *}$ & $.179^{* * *}$ & $.149^{* * *}$ & $.193^{* * *}$ & $.138^{* * *}$ & $.124^{* * *}$ & $.137^{* * *}$ & $.179^{* * *}$ & $.142^{* * *}$ & $.174^{* * *}$ & $.235^{* * *}$ & $.241^{* * *}$ \\
\hline & (.003) & $(.010)$ & $(.009)$ & $(.008)$ & $(.019)$ & $(.015)$ & (.008) & (.012) & $(.010)$ & $(.008)$ & $(.013)$ & $(.020)$ \\
\hline \multirow[t]{2}{*}{ Hourly deciles } & $.164^{* * *}$ & $.179^{* * *}$ & $.149^{* * *}$ & $.193^{* * *}$ & $.140^{* * *}$ & $.097^{* * *}$ & $.146^{* * *}$ & $.174^{* * *}$ & $.144^{* * *}$ & $.167^{* * *}$ & $.243^{* * *}$ & $.216^{* * *}$ \\
\hline & $(.003)$ & $(.010)$ & $(.009)$ & $(.008)$ & $(.018)$ & $(.017)$ & $(.009)$ & $(.012)$ & $(.009)$ & $(.008)$ & $(.013)$ & $(.014)$ \\
\hline \multirow[t]{2}{*}{ Hourly+bonus } & $.176^{* * *}$ & & $.151^{* * *}$ & & $.139^{* * *}$ & $.129^{* * *}$ & $.136^{* * *}$ & $.179^{* * *}$ & $.145^{* * *}$ & $.180^{* * *}$ & $.243^{* * *}$ & $.249^{* * *}$ \\
\hline & $(.003)$ & & $(.009)$ & & $(.019)$ & $(.017)$ & $(.009)$ & (.012) & $(.010)$ & $(.009)$ & $(.014)$ & $(.020)$ \\
\hline \multirow[t]{2}{*}{ Monthly } & $.172^{* * *}$ & & $.166^{* * *}$ & & $.133^{* * *}$ & $.128^{* * *}$ & $.164^{* * *}$ & $.175^{* * *}$ & $.149^{* * *}$ & $202^{* * *}$ & $266^{* * *}$ & $244^{* * *}$ \\
\hline & $(.003)$ & & $(.009)$ & & $(.018)$ & $(.015)$ & $(.011)$ & $(.013)$ & $(.011)$ & $(.009)$ & $(.016)$ & $(.020)$ \\
\hline \multirow[t]{2}{*}{ Monthly+bonus } & $.178^{* * *}$ & & $.170^{* * *}$ & & $.134^{* * *}$ & $.126^{* * *}$ & $.163^{* * *}$ & $.177^{* * *}$ & $.155^{* * *}$ & $.211^{* * *}$ & $.268^{* * *}$ & $.251^{* * *}$ \\
\hline & $(.004)$ & & $(.010)$ & & $(.018)$ & $(.015)$ & $(.011)$ & $(.013)$ & $(.009)$ & $(.010)$ & $(.017)$ & $(.020)$ \\
\hline Monthly+bonus & $.177^{* * *}$ & $196^{* * *}$ & $.164^{* * *}$ & $.215^{* * *}$ & $.134^{* * *}$ & $109^{* * *}$ & $166^{* * *}$ & $.171^{* * *}$ & $.163^{* * *}$ & $.203^{* * *}$ & $.275^{* * *}$ & $.257^{* * *}$ \\
\hline incl. self-emp. & $(.004)$ & $(.014)$ & $(.012)$ & $(.011)$ & $(.019)$ & $(.017)$ & $(.013)$ & $(.015)$ & $(.014)$ & $(.011)$ & $(.018)$ & $(.032)$ \\
\hline \multicolumn{2}{|l|}{ 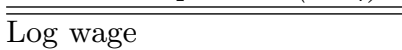 } & Italy & Japan & Korea & Netherl. & Norway & Poland & Slovak R. & Spain & Sweden $^{\dagger}$ & U.K. & U.S. \\
\hline \multirow{2}{*}{\multicolumn{2}{|c|}{ Hourly (baseline) }} & $.132^{* * *}$ & $.184^{* * *}$ & $.217^{* * *}$ & $.183^{* * *}$ & $.127^{* * *}$ & $.191^{* * *}$ & $.179^{* * *}$ & $.228^{* * *}$ & $.121^{* * *}$ & $225^{* * *}$ & $.279^{* * *}$ \\
\hline & & $(.016)$ & $(.014)$ & $(.014)$ & $(.011)$ & $(.007)$ & $(.017)$ & $(.019)$ & $(.017)$ & $(.009)$ & $(.013)$ & $(.017)$ \\
\hline \multirow{2}{*}{\multicolumn{2}{|c|}{ Hourly deciles }} & $122^{* * *}$ & $.182^{* * *}$ & $205^{* * *}$ & $.174^{* * *}$ & $.133^{* * *}$ & $.192^{* * *}$ & $.169^{* * *}$ & $.222^{* * *}$ & $.121^{* * *}$ & $.206^{* * *}$ & $.258^{* * *}$ \\
\hline & & $(.016)$ & $(.013)$ & $(.014)$ & $(.011)$ & $(.007)$ & $(.017)$ & $(.017)$ & $(.015)$ & $(.009)$ & $(.013)$ & $(.021)$ \\
\hline \multirow{2}{*}{\multicolumn{2}{|c|}{ Hourly+bonus }} & $.144^{* * *}$ & $.195^{* * *}$ & $226^{* * *}$ & $.190^{* * *}$ & $.134^{* * *}$ & $.193^{* * *}$ & $.192^{* * *}$ & $.243^{* * *}$ & & $230^{* * *}$ & $.285^{* * *}$ \\
\hline & & $(.018)$ & $(.014)$ & $(.015)$ & $(.012)$ & $(.008)$ & $(.017)$ & $(.020)$ & $(.017)$ & & $(.013)$ & $(.018)$ \\
\hline \multirow[t]{2}{*}{ Monthly } & & $.123^{* * *}$ & $.180^{* * *}$ & $166^{* * *}$ & $.193^{* * *}$ & $.151^{* * *}$ & $.173^{* * *}$ & $.182^{* * *}$ & $.203^{* * *}$ & & $.227^{* * *}$ & $.315^{* * *}$ \\
\hline & & $(.017)$ & $(.013)$ & $(.013)$ & $(.012)$ & $(.010)$ & $(.017)$ & $(.020)$ & $(.016)$ & & $(.014)$ & $(.018)$ \\
\hline \multirow[t]{2}{*}{ Monthly+bonus } & & $.140^{* * *}$ & $.190^{* * *}$ & $.181^{* * *}$ & $.198^{* * *}$ & $.154^{* * *}$ & $.180^{* * *}$ & $.195^{* * *}$ & $.218^{* * *}$ & & $.225^{* * *}$ & $.321^{* * *}$ \\
\hline & & $(.019)$ & $(.014)$ & $(.013)$ & $(.013)$ & $(.010)$ & $(.017)$ & $(.020)$ & $(.016)$ & & $(.016)$ & $(.019)$ \\
\hline Monthly+bonus & & $.145^{* * *}$ & $.184^{* * *}$ & $187^{* * *}$ & $.189^{* * *}$ & $.161^{* * *}$ & $.195^{* * *}$ & $.177^{* * *}$ & $.204^{* * *}$ & $.127^{* * *}$ & $.230^{* * *}$ & $.306^{* * *}$ \\
\hline incl. self-emp. & & $(.020)$ & $(.014)$ & $(.016)$ & $(.013)$ & $(.011)$ & $(.020)$ & (.022) & $(.016)$ & $(.012)$ & $(.021)$ & $(.019)$ \\
\hline
\end{tabular}

Notes: Each cell reports the coefficient on numeracy skills from a separate regression. Least squares regressions weighted by sampling weights. Dependent variable: log gross earnings, different measures as indicated in first column. Hourly (baseline): log gross hourly wage excluding bonuses (measured continuously, replicates Table 2). Hourly deciles: log gross hourly wage measured as decile medians. Hourly+bonuses: log gross hourly wage including bonuses. Monthly: log gross monthly wage excluding bonuses. Monthly+bonuses: log gross monthly wage including bonuses. Monthly+bonuses incl. self-employed: log gross monthly wage including bonuses for sample including self-employed. Sample: full-time employees aged 35-54 (Canada includes part-time employees). All regressions control for gender and a quadratic polynomial in actual work experience. Numeracy score standardized to std. dev. 1 within each country. Pooled specification includes country fixed effects and gives same weight to each country. All pooled models exclude Austria, Canada, Germany, Sweden, and U.S., where continuous earnings data are not available in the Public Use File that pools all countries. Robust standard errors in parentheses. ${ }^{\dagger}$ Models in Austria, Canada, and Sweden refer to earnings measured as decile medians. Data source: PIAAC. 
Figure 1: Returns to Skills around the World

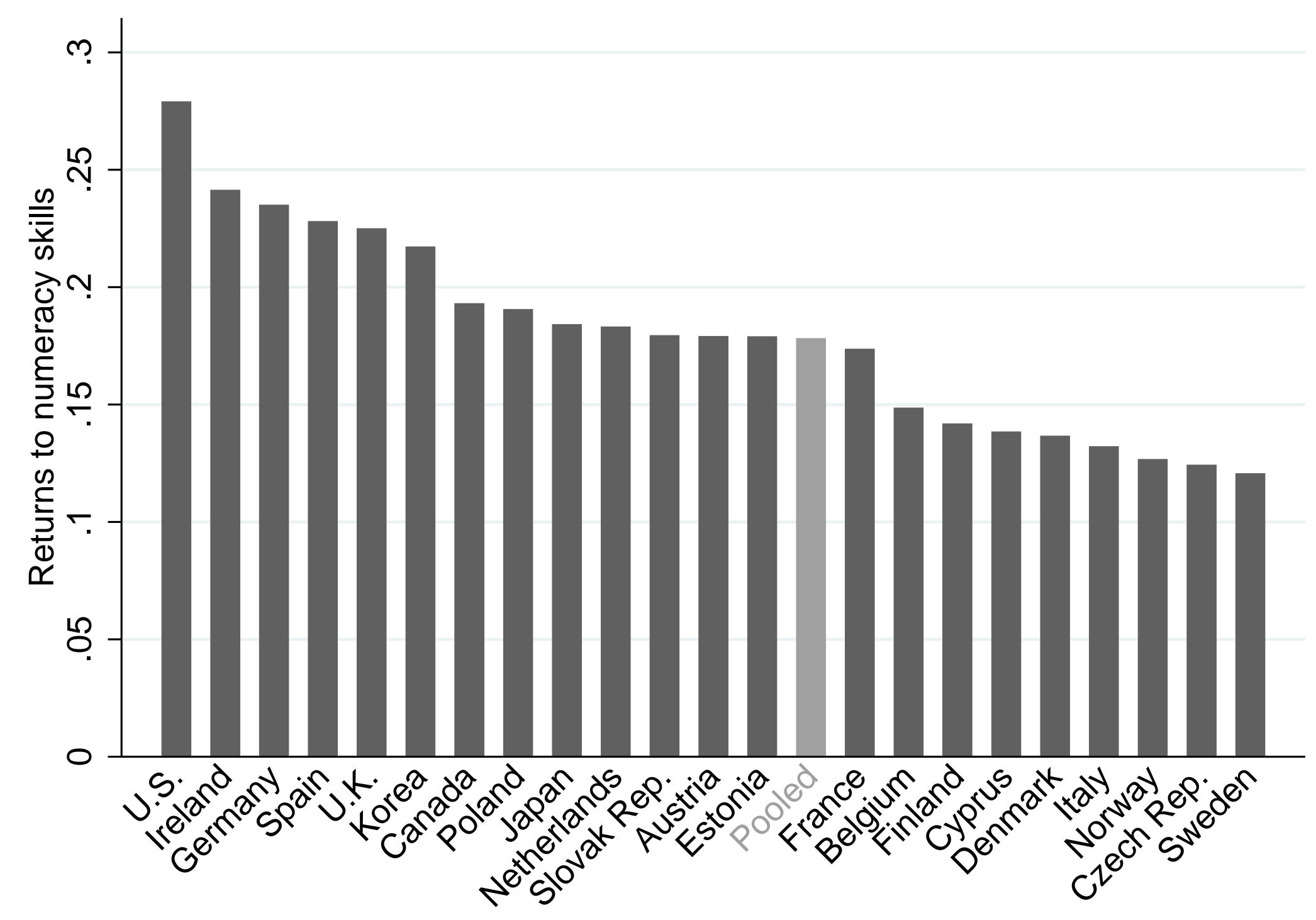

Notes: Coefficient estimates on numeracy score (standardized to std. dev. 1 within each country) in a regression of log gross hourly wage on numeracy, gender, and a quadratic polynomial in actual work experience, sample of full-time employees aged 35-54. Replicates baseline model from Table 2. Data source: PIAAC. 


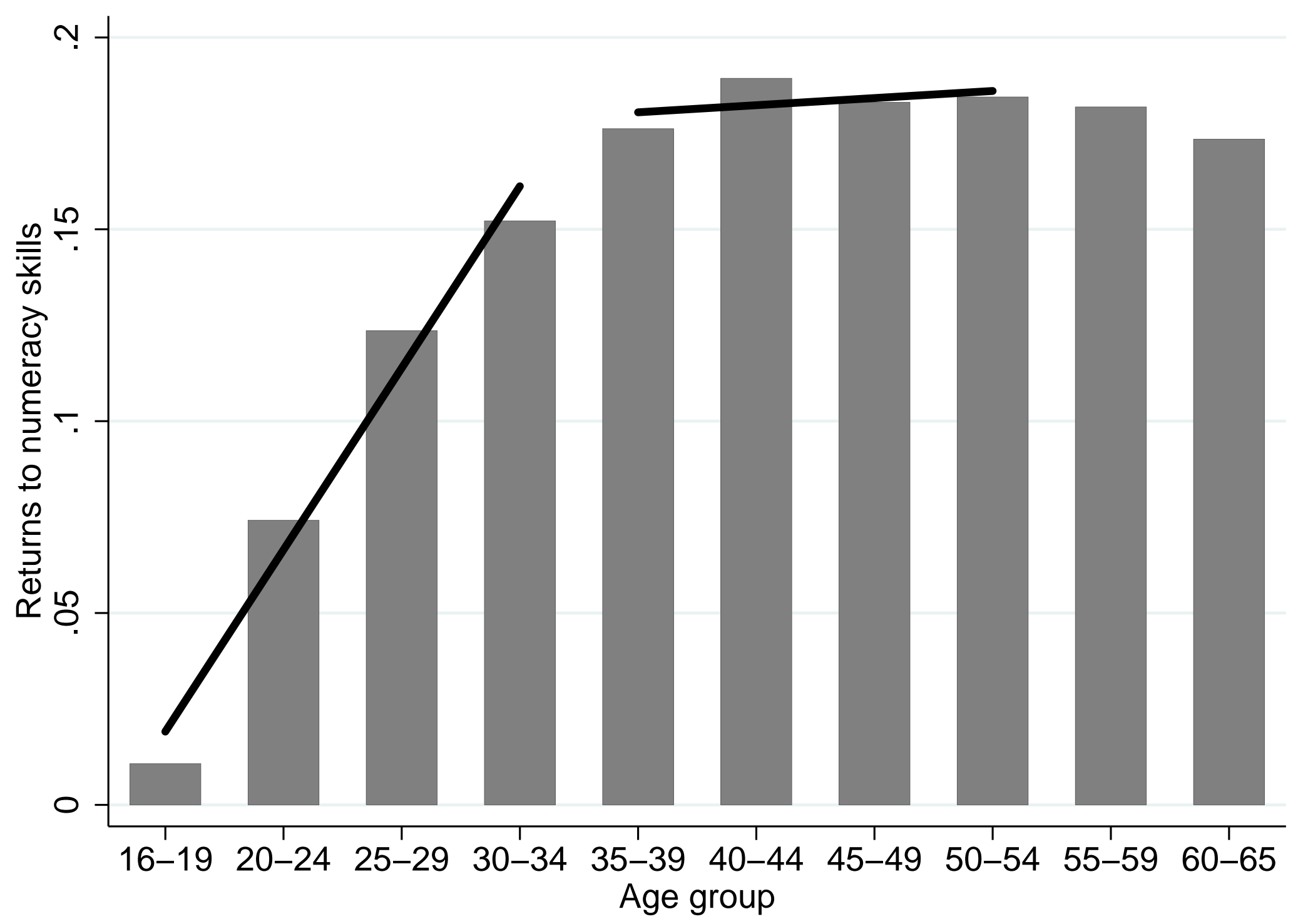

Notes: Coefficient estimates on numeracy score (standardized to std. dev. 1 within each country) for indicated 5-year age groups in a regression of log gross hourly wage on numeracy, gender, a quadratic polynomial in actual work experience, and country fixed effects, sample of full-time employees pooling all countries. Slopes of solid lines reflect average change in returns by age groups (separately estimated for ages 16-34 and 35-54). Data source: PIAAC. 
Figure 3: Returns to Skills in Alternative Subgroups

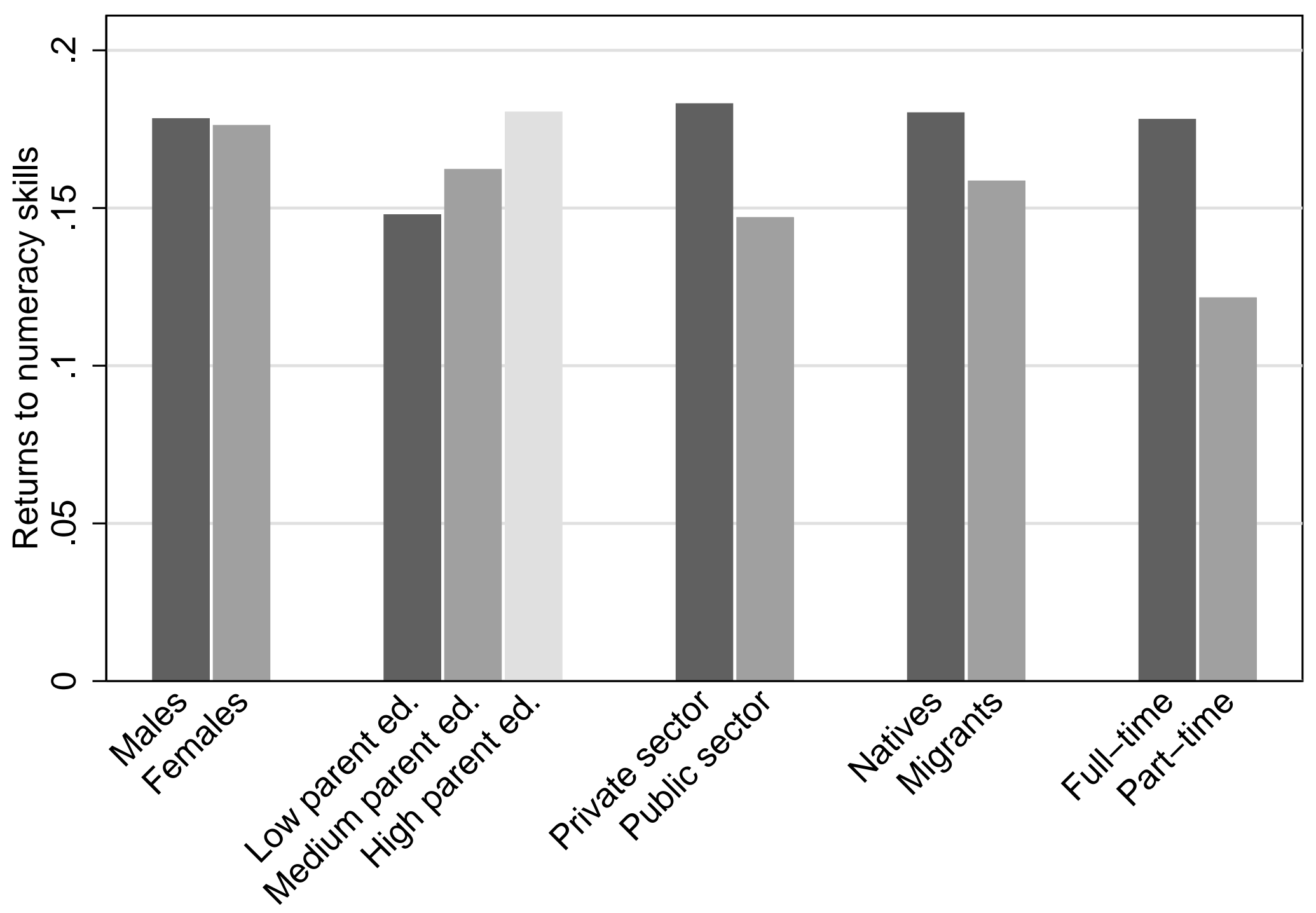

Notes: Coefficient estimates on numeracy score (standardized to std. dev. 1 within each country) for indicated subgroup in a regression of $\log$ gross hourly wage on numeracy, gender, a quadratic polynomial in actual work experience, and country fixed effects, sample of full-time employees aged 35-54 pooling all countries. Replicates fully interacted model from Table A-4. With the exception of gender, all subgroup differences are statistically significant at the 5 percent level. Data source: PIAAC. 
Table 1: Descriptive Statistics

\begin{tabular}{|c|c|c|c|c|c|c|c|c|c|c|c|c|}
\hline & Pooled & Austria & Belgium & Canada & Cyprus & Czech R. & Denmark & Estonia & Finland & France & Germany & Ireland \\
\hline $\begin{array}{l}\text { Gross hourly wage } \\
\text { (national currency) }\end{array}$ & & $\begin{array}{l}15.3 \\
(6.1)\end{array}$ & $\begin{array}{l}18.0 \\
(6.1)\end{array}$ & $\begin{array}{l}27.4 \\
(11.9)\end{array}$ & $\begin{array}{l}11.9 \\
(6.7)\end{array}$ & $\begin{array}{l}117.0 \\
(50.8)\end{array}$ & $\begin{array}{l}198.5 \\
(62.4)\end{array}$ & $\begin{array}{l}5.2 \\
(3.3)\end{array}$ & $\begin{array}{l}18.6 \\
(6.7)\end{array}$ & $\begin{array}{l}13.7 \\
(5.6)\end{array}$ & $\begin{array}{l}17.2 \\
(7.8)\end{array}$ & $\begin{array}{c}21.3 \\
(10.3)\end{array}$ \\
\hline Wage inequality & 1.11 & 1.07 & 0.85 & 1.25 & 1.26 & 0.96 & 0.78 & 1.51 & 0.88 & 0.86 & 1.35 & 1.20 \\
\hline Numeracy & $\begin{array}{l}279.0 \\
(49.8)\end{array}$ & $\begin{array}{l}282.1 \\
(49.2)\end{array}$ & $\begin{array}{l}290.4 \\
(49.6)\end{array}$ & $\begin{array}{l}271.9 \\
(53.5)\end{array}$ & $\begin{array}{l}273.8 \\
(44.5)\end{array}$ & $\begin{array}{l}274.2 \\
(43.1)\end{array}$ & $\begin{array}{l}291.9 \\
(45.3)\end{array}$ & $\begin{array}{l}275.1 \\
(44.0)\end{array}$ & $\begin{array}{l}293.5 \\
(47.6)\end{array}$ & $\begin{array}{l}262.7 \\
(53.0)\end{array}$ & $\begin{array}{l}285.4 \\
(49.5)\end{array}$ & $\begin{array}{l}271.9 \\
(49.9)\end{array}$ \\
\hline Yrs schooling & $\begin{array}{l}13.3 \\
(2.9)\end{array}$ & $\begin{array}{l}12.4 \\
(2.6)\end{array}$ & $\begin{array}{l}13.0 \\
(2.6)\end{array}$ & $\begin{array}{l}13.9 \\
(2.5)\end{array}$ & $\begin{array}{l}13.1 \\
(2.8)\end{array}$ & $\begin{array}{l}13.2 \\
(2.4)\end{array}$ & $\begin{array}{l}13.3 \\
(2.5)\end{array}$ & $\begin{array}{l}12.5 \\
(2.6)\end{array}$ & $\begin{array}{l}13.4 \\
(2.8)\end{array}$ & $\begin{array}{l}11.8 \\
(3.4)\end{array}$ & $\begin{array}{l}14.3 \\
(2.5)\end{array}$ & $\begin{array}{l}15.7 \\
(2.8)\end{array}$ \\
\hline Experience (years) & $\begin{array}{l}22.3 \\
(7.8)\end{array}$ & $\begin{array}{l}24.9 \\
(7.4)\end{array}$ & $\begin{array}{l}23.2 \\
(7.0)\end{array}$ & $\begin{array}{l}23.5 \\
(8.0)\end{array}$ & $\begin{array}{l}22.0 \\
(7.5)\end{array}$ & $\begin{array}{l}22.4 \\
(7.4)\end{array}$ & $\begin{array}{l}24.4 \\
(7.8)\end{array}$ & $\begin{array}{l}22.0 \\
(7.2)\end{array}$ & $\begin{array}{l}21.0 \\
(7.4)\end{array}$ & $\begin{array}{l}22.5 \\
(8.0)\end{array}$ & $\begin{array}{l}23.3 \\
(7.5)\end{array}$ & $\begin{array}{l}22.0 \\
(7.7)\end{array}$ \\
\hline Female (share) & 0.44 & 0.34 & 0.39 & 0.49 & 0.46 & 0.50 & 0.49 & 0.56 & 0.51 & 0.44 & 0.39 & 0.41 \\
\hline Observations & 34447 & 1115 & 1220 & 7178 & 938 & 1066 & 1875 & 1767 & 1478 & 1715 & 1296 & 1031 \\
\hline & & Italy & Japan & Korea & Netherl. & Norway & Poland & Slovak R. & Spain & Sweden & U.K. & U.S. \\
\hline $\begin{array}{l}\text { Gross hourly wage } \\
\text { (national currency) }\end{array}$ & & $\begin{array}{l}11.7 \\
(5.5)\end{array}$ & $\begin{array}{l}1.9^{\dagger} \\
(1.1)\end{array}$ & $\begin{array}{l}13.0^{\dagger} \\
(8.7)\end{array}$ & $\begin{array}{l}19.7 \\
(7.7)\end{array}$ & $\begin{array}{l}235.8 \\
(75.2)\end{array}$ & $\begin{array}{l}16.4 \\
(9.2)\end{array}$ & $\begin{array}{l}4.4 \\
(2.7)\end{array}$ & $\begin{array}{l}10.4 \\
(5.2)\end{array}$ & $\begin{array}{l}172.2 \\
(49.4)\end{array}$ & $\begin{array}{l}14.3 \\
(7.6)\end{array}$ & $\begin{array}{c}24.3 \\
(15.0)\end{array}$ \\
\hline Wage inequality & & 1.02 & 1.31 & 1.50 & 1.06 & 0.80 & 1.25 & 1.22 & 1.21 & 0.69 & 1.20 & 1.49 \\
\hline Numeracy & & $\begin{array}{l}256.1 \\
(47.7)\end{array}$ & $\begin{array}{l}300.2 \\
(42.1)\end{array}$ & $\begin{array}{l}265.9 \\
(43.5)\end{array}$ & $\begin{array}{l}292.7 \\
(47.0)\end{array}$ & $\begin{array}{l}294.4 \\
(48.9)\end{array}$ & $\begin{array}{l}261.9 \\
(46.8)\end{array}$ & $\begin{array}{l}286.6 \\
(40.3)\end{array}$ & $\begin{array}{l}260.3 \\
(46.7)\end{array}$ & $\begin{array}{l}288.0 \\
(50.6)\end{array}$ & $\begin{array}{l}274.0 \\
(51.9)\end{array}$ & $\begin{array}{l}266.0 \\
(54.7)\end{array}$ \\
\hline Yrs schooling & & $\begin{array}{l}11.1 \\
(3.6)\end{array}$ & $\begin{array}{l}13.6 \\
(2.4)\end{array}$ & $\begin{array}{l}13.4 \\
(3.0)\end{array}$ & $\begin{array}{l}14.0 \\
(2.5)\end{array}$ & $\begin{array}{l}14.9 \\
(2.3)\end{array}$ & $\begin{array}{l}13.3 \\
(2.9)\end{array}$ & $\begin{array}{l}13.6 \\
(2.5)\end{array}$ & $\begin{array}{l}12.5 \\
(3.5)\end{array}$ & $\begin{array}{l}12.8 \\
(2.4)\end{array}$ & $\begin{array}{l}13.2 \\
(2.3)\end{array}$ & $\begin{array}{l}14.3 \\
(2.9)\end{array}$ \\
\hline Experience (years) & & $\begin{array}{l}20.8 \\
(8.4)\end{array}$ & $\begin{array}{l}21.3 \\
(7.0)\end{array}$ & $\begin{array}{l}16.2 \\
(7.9)\end{array}$ & $\begin{array}{l}22.9 \\
(7.3)\end{array}$ & $\begin{array}{l}22.2 \\
(7.4)\end{array}$ & $\begin{array}{l}20.7 \\
(7.7)\end{array}$ & $\begin{array}{l}22.4 \\
(7.0)\end{array}$ & $\begin{array}{l}20.5 \\
(8.0)\end{array}$ & $\begin{array}{l}22.4 \\
(7.7)\end{array}$ & $\begin{array}{l}24.5 \\
(7.4)\end{array}$ & $\begin{array}{l}24.0 \\
(8.1)\end{array}$ \\
\hline Female (share) & & 0.36 & 0.35 & 0.40 & 0.27 & 0.44 & 0.47 & 0.51 & 0.41 & 0.49 & 0.39 & 0.50 \\
\hline Observations & & 1018 & 1322 & 1441 & 1013 & 1520 & 816 & 1198 & 1191 & 1316 & 1786 & 1105 \\
\hline
\end{tabular}

Notes: Means, standard deviations (in parentheses), and numbers of observations for selected variables by country. Sample: full-time employees aged 35-54 (Canada includes part-time employees). Full-time workers are defined as those working at least 30 hours per week (except for Austria, where classification is based on respondents' reports of whether they work full-time). Wage inequality: log wage differential between 90th and 10th percentile of wage distribution. Pooled specification gives same weight to each country. ${ }^{\dagger}$ wages divided by 1000. Data source: PIAAC. 
Table 2: Returns to Skills around the World

\begin{tabular}{|c|c|c|c|c|c|c|c|c|c|c|c|c|}
\hline & Pooled & Austria & Belgium & Canada & Cyprus & Czech R. & Denmark & Estonia & Finland & France & Germany & Ireland \\
\hline \multirow[t]{2}{*}{ Numeracy } & $.178^{* * *}$ & $.179^{* * *}$ & $.149^{* * *}$ & $.193^{* * *}$ & $.138^{* * *}$ & $.124^{* * *}$ & $.137^{* * *}$ & $.179^{* * *}$ & $.142^{* * *}$ & $.174^{* * *}$ & $.235^{* * *}$ & $.241^{* * *}$ \\
\hline & (.003) & $(.010)$ & $(.009)$ & $(.008)$ & $(.019)$ & $(.015)$ & $(.008)$ & (.012) & $(.010)$ & $(.008)$ & $(.013)$ & $(.020)$ \\
\hline \multirow[t]{2}{*}{ Experience } & $.023^{* * *}$ & .009 & $.016^{* *}$ & $.020^{* * *}$ & $.033^{* * *}$ & $.016^{* *}$ & .001 & $.028^{* * *}$ & $.015^{* * *}$ & $.021^{* * *}$ & .003 & $.028^{* *}$ \\
\hline & (.002) & $(.007)$ & $(.006)$ & (.004) & $(.008)$ & $(.008)$ & (.004) & (.009) & $(.006)$ & $(.005)$ & $(.008)$ & (.012) \\
\hline \multirow[t]{2}{*}{ Experience $^{2}$} & $-.041^{* * *}$ & -.012 & $-.024^{*}$ & $-.030^{* * *}$ & $-.054^{* * *}$ & $-.039^{* *}$ & -.000 & $-.079^{* * *}$ & $-.032^{* *}$ & $-.030^{* * *}$ & .008 & -.043 \\
\hline & (.003) & $(.015)$ & $(.014)$ & (.009) & $(.018)$ & (.019) & $(.008)$ & (.021) & (.013) & $(.011)$ & $(.018)$ & $(.027)$ \\
\hline \multirow[t]{2}{*}{ Female } & $-.150^{* * *}$ & $-.136^{* * *}$ & -.020 & $-.115^{* * *}$ & $-.199^{* * *}$ & $-.213^{* * *}$ & $-.088^{* * *}$ & $-.399^{* * *}$ & $-.170^{* * *}$ & $-.092^{* * *}$ & $-.105^{* * *}$ & .031 \\
\hline & $(.005)$ & (.024) & $(.018)$ & $(.015)$ & $(.036)$ & $(.035)$ & $(.014)$ & $(.024)$ & $(.017)$ & $(.016)$ & $(.026)$ & $(.034)$ \\
\hline $\mathrm{R}^{2}$ & .209 & .260 & .202 & .226 & .154 & .207 & .185 & .259 & .255 & .239 & .258 & .211 \\
\hline \multirow[t]{2}{*}{ Observations } & 34447 & 1115 & 1220 & 7178 & 938 & 1066 & 1875 & 1767 & 1478 & 1715 & 1296 & 1031 \\
\hline & & Italy & Japan & Korea & Netherl. & Norway & Poland & Slovak R. & Spain & Sweden & "U.K. & U.S. \\
\hline \multirow[t]{2}{*}{ Numeracy } & & $.132^{* * *}$ & $.184^{* * *}$ & $.217^{* * *}$ & $.183^{* * *}$ & $.127^{* * *}$ & $.191^{* * *}$ & $.179^{* * *}$ & $.228^{* * *}$ & $.121^{* * *}$ & $.225^{* * *}$ & $.279^{* * *}$ \\
\hline & & $(.016)$ & $(.014)$ & $(.014)$ & $(.011)$ & $(.007)$ & $(.017)$ & $(.019)$ & $(.017)$ & $(.009)$ & $(.013)$ & $(.017)$ \\
\hline \multirow[t]{2}{*}{ Experience } & & .011 & $.018^{* *}$ & $.033^{* * *}$ & $.019^{* * *}$ & $.021^{* * *}$ & $.046^{* * *}$ & .011 & $.024^{* * *}$ & $.017^{* * *}$ & .000 & $.018^{* *}$ \\
\hline & & $(.008)$ & $(.007)$ & $(.006)$ & $(.007)$ & $(.005)$ & $(.008)$ & $(.012)$ & $(.008)$ & $(.005)$ & $(.009)$ & $(.009)$ \\
\hline \multirow[t]{2}{*}{ Experience $^{2}$} & & -.005 & -.012 & $-.056^{* * *}$ & $-.036^{* *}$ & $-.045^{* * *}$ & $-.095^{* * *}$ & -.030 & $-.037^{* *}$ & $-.032^{* * *}$ & -.002 & $-.035^{* *}$ \\
\hline & & (.019) & $(.018)$ & $(.016)$ & $(.015)$ & $(.011)$ & (.020) & $(.027)$ & $(.017)$ & $(.010)$ & $(.018)$ & $(.018)$ \\
\hline \multirow[t]{2}{*}{ Female } & & $-.121^{* * *}$ & $-.329^{* * *}$ & $-.384^{* * *}$ & .013 & $-.119^{* * *}$ & $-.122^{* * *}$ & $-.250^{* * *}$ & -.023 & $-.090^{* * *}$ & $-.081^{* * *}$ & $-.176^{* * *}$ \\
\hline & & (.028) & $(.027)$ & $(.030)$ & $(.024)$ & $(.014)$ & (.033) & $(.030)$ & $(.027)$ & $(.014)$ & (.026) & (.032) \\
\hline $\mathrm{R}^{2}$ & & .162 & .309 & .343 & .218 & .220 & .201 & .169 & .214 & .217 & .241 & .308 \\
\hline Observations & & 1018 & 1322 & 1441 & 1013 & 1520 & 816 & 1198 & 1191 & 1316 & 1786 & 1105 \\
\hline
\end{tabular}

Notes: Least squares regressions weighted by sampling weights. Dependent variable: log gross hourly wage. Sample: full-time employees aged 35-54 (Canada includes part-time employees). Numeracy score standardized to std. dev. 1 within each country. Experience ${ }^{2}$ divided by 1000. Pooled specification includes country fixed effects and gives same weight to each country; $\mathrm{R}^{2}$ refers to within-country $\mathrm{R}^{2}$. Robust standard errors in parentheses. Data source: PIAAC. 
Table 3: The Age Pattern of Returns to Skills

\begin{tabular}{|c|c|c|c|c|c|c|c|c|c|c|c|c|}
\hline & Pooled & Austria & Belgium & Canada & Cyprus & Czech R. & Denmark & Estonia & Finland & France & Germany & Ireland \\
\hline \multirow[t]{2}{*}{ Numeracy } & $.140^{* * *}$ & $.107^{* * *}$ & $.116^{* * *}$ & $.155^{* * *}$ & $.111^{* * *}$ & $.121^{* * *}$ & $.088^{* * *}$ & $.170^{* * *}$ & $.105^{* * *}$ & $.141^{* * *}$ & $.189^{* * *}$ & $.136^{* * *}$ \\
\hline & $(.004)$ & $(.017)$ & $(.012)$ & $(.014)$ & $(.018)$ & $(.024)$ & (.012) & $(.017)$ & $(.011)$ & $(.013)$ & $(.021)$ & $(.017)$ \\
\hline \multirow[t]{2}{*}{$\times$ Prime Age } & $.042^{* * *}$ & $.074^{* * *}$ & $.032^{* *}$ & $.039^{* *}$ & .032 & .008 & $.050^{* * *}$ & .013 & $.040^{* * *}$ & $.034^{* *}$ & $.045^{*}$ & $.105^{* * *}$ \\
\hline & $(.005)$ & $(.020)$ & $(.015)$ & $(.016)$ & $(.026)$ & $(.028)$ & $(.015)$ & $(.021)$ & $(.015)$ & $(.015)$ & $(.025)$ & $(.026)$ \\
\hline \multirow[t]{2}{*}{$\times$ Exit Age } & $.038^{* * *}$ & $.131^{* * *}$ & $.088^{* * *}$ & $.040^{* *}$ & $.087^{* *}$ & .007 & $.043^{* * *}$ & -.041 & .028 & $.053^{* *}$ & -.015 & $.180^{* * *}$ \\
\hline & $(.007)$ & $(.033)$ & $(.028)$ & $(.020)$ & $(.037)$ & $(.046)$ & $(.015)$ & $(.027)$ & $(.019)$ & $(.021)$ & $(.040)$ & $(.061)$ \\
\hline \multirow[t]{2}{*}{ Prime Age } & $.030^{* * *}$ & $.062^{* *}$ & $.076^{* * *}$ & $.065^{* * *}$ & .042 & -.046 & $.084^{* * *}$ & $-.094^{* * *}$ & $.102^{* * *}$ & $.054^{* * *}$ & .052 & $.071^{* *}$ \\
\hline & $(.007)$ & $(.027)$ & (.022) & $(.019)$ & $(.036)$ & $(.042)$ & $(.018)$ & $(.035)$ & (.022) & $(.020)$ & $(.035)$ & $(.036)$ \\
\hline \multirow[t]{2}{*}{ Exit Age } & $.034^{* * *}$ & $.186^{* * *}$ & $.166^{* * *}$ & -.003 & .069 & .071 & $.089^{* * *}$ & $-.097^{*}$ & $.130^{* * *}$ & $.099^{* * *}$ & $.103^{* *}$ & .095 \\
\hline & $(.010)$ & $(.047)$ & $(.042)$ & $(.027)$ & $(.065)$ & (.072) & $(.025)$ & $(.051)$ & $(.034)$ & $(.031)$ & $(.052)$ & (.062) \\
\hline $\mathrm{R}^{2}$ & .197 & .261 & .244 & .216 & .199 & .179 & .193 & .241 & .237 & .260 & .237 & .246 \\
\hline \multirow[t]{2}{*}{ Observations } & 61384 & 1799 & 2026 & 12396 & 1769 & 2053 & 3593 & 3259 & 2705 & 2897 & 2211 & 1871 \\
\hline & & Italy & Japan & Korea & Netherl. & Norway & Poland & Slovak R. & Spain & Sweden & U.K. & U.S. \\
\hline \multirow[t]{2}{*}{ Numeracy } & & $.094^{* * *}$ & $.128^{* * *}$ & $.176^{* * *}$ & $.131^{* * *}$ & $.104^{* * *}$ & $.184^{* * *}$ & $.183^{* * *}$ & $.196^{* * *}$ & $.046^{* * *}$ & $.188^{* * *}$ & $.226^{* * *}$ \\
\hline & & $(.021)$ & $(.017)$ & (.021) & (.019) & $(.013)$ & (.022) & $(.025)$ & (.022) & $(.011)$ & $(.018)$ & $(.018)$ \\
\hline \multirow[t]{2}{*}{$\times$ Prime Age } & & .037 & $.055^{* *}$ & $.053^{* *}$ & $.054^{* *}$ & $.026^{*}$ & .010 & -.002 & .035 & $.076^{* * *}$ & $.039^{*}$ & $.057^{* *}$ \\
\hline & & $(.027)$ & (.022) & $(.025)$ & (.022) & $(.015)$ & $(.028)$ & $(.031)$ & $(.027)$ & $(.015)$ & (.022) & $(.024)$ \\
\hline \multirow[t]{2}{*}{$\times$ Exit Age } & & $.123^{* * *}$ & $.054^{*}$ & .058 & $.057^{* *}$ & .012 & -.024 & $.090^{* *}$ & .011 & $.073^{* * *}$ & .010 & .018 \\
\hline & & $(.039)$ & $(.031)$ & $(.044)$ & $(.024)$ & (.022) & $(.043)$ & $(.038)$ & $(.036)$ & $(.018)$ & $(.029)$ & $(.034)$ \\
\hline \multirow[t]{2}{*}{ Prime Age } & & $.099^{* * *}$ & .024 & $-.061^{* *}$ & $.177^{* * *}$ & $.071^{* * *}$ & $-.133^{* * *}$ & -.060 & .054 & .030 & $.129^{* * *}$ & $.148^{* * *}$ \\
\hline & & (.033) & $(.028)$ & $(.028)$ & $(.031)$ & $(.020)$ & $(.040)$ & $(.042)$ & (.033) & $(.020)$ & (.032) & $(.034)$ \\
\hline \multirow[t]{2}{*}{ Exit Age } & & $.141^{* *}$ & -.052 & $-.210^{* * *}$ & $.254^{* * *}$ & $.108^{* * *}$ & $-.157^{* *}$ & -.016 & .050 & $.047^{*}$ & .034 & $.228^{* * *}$ \\
\hline & & $(.057)$ & $(.047)$ & $(.058)$ & $(.044)$ & $(.030)$ & $(.066)$ & $(.059)$ & $(.056)$ & $(.028)$ & $(.051)$ & $(.054)$ \\
\hline $\mathrm{R}^{2}$ & & .195 & .298 & .276 & .265 & .234 & .176 & .171 & .234 & .210 & .243 & .296 \\
\hline Observations & & 1534 & 2405 & 2490 & 1777 & 2596 & 2158 & 2105 & 1962 & 2381 & 3200 & 2143 \\
\hline
\end{tabular}

Notes: Least squares regressions weighted by sampling weights. Dependent variable: log gross hourly wage. Sample: full-time employees aged 25-65 (Canada includes part-time employees). Prime age: 35-54 years. Exit age: 55-65 years. Coefficient on numeracy reflects returns to numeracy skills for baseline category, i.e., entry-age workers (25-34 years). All regressions control for gender and a quadratic polynomial in actual work experience. Numeracy score standardized to std. dev. 1 within each country. Pooled specification includes country fixed effects and gives same weight to each country; $\mathrm{R}^{2}$ refers to within-country $\mathrm{R}^{2}$. Robust standard errors in parentheses. Data source: PIAAC. 
Table 4: Skills, Years of Schooling, and Earnings

\begin{tabular}{|c|c|c|c|c|c|c|c|c|c|c|c|c|}
\hline & Pooled & Austria & Belgium & Canada & Cyprus & Czech R. & Denmark & Estonia & Finland & France & Germany & Ireland \\
\hline \multirow[t]{2}{*}{ Numeracy } & $.101^{* * *}$ & $.120^{* * *}$ & $.089^{* * *}$ & $.129^{* * *}$ & $.057^{* * *}$ & $.074^{* * *}$ & $.085^{* * *}$ & $.116^{* * *}$ & $.079^{* * *}$ & $.094^{* * *}$ & $.148^{* * *}$ & $.151^{* * *}$ \\
\hline & (.003) & $(.010)$ & $(.010)$ & $(.008)$ & $(.018)$ & $(.020)$ & $(.009)$ & $(.014)$ & $(.011)$ & $(.009)$ & $(.014)$ & $(.021)$ \\
\hline \multirow[t]{2}{*}{ Yrs schooling } & $.059^{* * *}$ & $.058^{* * *}$ & $.045^{* * *}$ & $.057^{* * *}$ & $.082^{* * *}$ & $.045^{* * *}$ & $.043^{* * *}$ & $.055^{* * *}$ & $.057^{* * *}$ & $.041^{* * *}$ & $.064^{* * *}$ & $.060^{* * *}$ \\
\hline & $(.001)$ & $(.004)$ & $(.004)$ & $(.003)$ & $(.007)$ & $(.010)$ & (.003) & $(.005)$ & (.003) & $(.003)$ & $(.005)$ & $(.007)$ \\
\hline \multirow[t]{2}{*}{ Experience } & $.022^{* * *}$ & $.016^{* *}$ & $.011^{*}$ & $.020^{* * *}$ & $.020^{* *}$ & $.015^{*}$ & $.007^{*}$ & $.024^{* * *}$ & $.014^{* * *}$ & $.018^{* * *}$ & .009 & $.030^{* * *}$ \\
\hline & $(.001)$ & $(.007)$ & $(.006)$ & $(.004)$ & $(.008)$ & $(.008)$ & $(.004)$ & $(.009)$ & $(.005)$ & $(.005)$ & $(.008)$ & $(.011)$ \\
\hline \multirow[t]{2}{*}{ Experience $^{2}$} & $-.032^{* * *}$ & -.019 & -.006 & $-.024^{* * *}$ & -.002 & -.029 & -.006 & $-.069^{* * *}$ & -.014 & $-.018^{*}$ & -.004 & -.040 \\
\hline & (.003) & $(.013)$ & $(.013)$ & (.008) & (.019) & $(.019)$ & $(.008)$ & (.020) & $(.012)$ & $(.010)$ & $(.017)$ & $(.024)$ \\
\hline \multirow[t]{2}{*}{ Female } & $-.176^{* * *}$ & $-.119^{* * *}$ & $-.050^{* * *}$ & $-.131^{* * *}$ & $-.193^{* * *}$ & $-.196^{* * *}$ & $-.116^{* * *}$ & $-.442^{* * *}$ & $-.205^{* * *}$ & $-.118^{* * *}$ & $-.125^{* * *}$ & -.029 \\
\hline & $(.005)$ & (.022) & $(.017)$ & $(.014)$ & (.034) & (.033) & (.013) & (.024) & $(.015)$ & $(.015)$ & (.024) & (.033) \\
\hline $\mathrm{R}^{2}$ & .308 & .370 & .286 & .303 & .315 & .262 & .282 & .310 & .414 & .331 & .338 & .286 \\
\hline \multirow[t]{2}{*}{ Observations } & 34159 & 1115 & 1219 & 7155 & 938 & 1065 & 1875 & 1767 & 1478 & 1707 & 1296 & 1031 \\
\hline & & Italy & Japan & Korea & Netherl. & Norway & Poland & Slovak R. & Spain & Sweden & U.K. & U.S. \\
\hline \multirow[t]{2}{*}{ Numeracy } & & $.057^{* * *}$ & $.114^{* * *}$ & $.102^{* * *}$ & $.111^{* * *}$ & $.082^{* * *}$ & $.071^{* * *}$ & $.086^{* * *}$ & $.104^{* * *}$ & $.089^{* * *}$ & $.173^{* * *}$ & $.138^{* * *}$ \\
\hline & & $(.016)$ & $(.015)$ & $(.015)$ & $(.012)$ & $(.008)$ & $(.015)$ & $(.018)$ & $(.018)$ & $(.010)$ & $(.016)$ & (.022) \\
\hline \multirow[t]{2}{*}{ Yrs schooling } & & $.046^{* * *}$ & $.067^{* * *}$ & $.076^{* * *}$ & $.063^{* * *}$ & $.042^{* * *}$ & $.090^{* * *}$ & $.084^{* * *}$ & $.066^{* * *}$ & $.026^{* * *}$ & $.061^{* * *}$ & $.081^{* * *}$ \\
\hline & & $(.004)$ & $(.006)$ & $(.005)$ & $(.006)$ & $(.003)$ & $(.006)$ & $(.006)$ & $(.004)$ & $(.004)$ & $(.007)$ & $(.007)$ \\
\hline \multirow[t]{2}{*}{ Experience } & & .011 & $.022^{* * *}$ & $.025^{* * *}$ & $.027^{* * *}$ & $.023^{* * *}$ & $.027^{* * *}$ & .013 & $.021^{* * *}$ & $.017^{* * *}$ & .009 & $.015^{*}$ \\
\hline & & $(.007)$ & $(.007)$ & $(.005)$ & $(.006)$ & $(.005)$ & $(.007)$ & (.012) & $(.007)$ & $(.004)$ & $(.009)$ & $(.008)$ \\
\hline \multirow[t]{2}{*}{ Experience $^{2}$} & & .007 & -.009 & -.019 & $-.044^{* * *}$ & $-.042^{* * *}$ & $-.044^{* *}$ & -.023 & -.024 & $-.028^{* * *}$ & -.009 & $-.028^{*}$ \\
\hline & & $(.017)$ & $(.018)$ & $(.015)$ & $(.014)$ & $(.011)$ & $(.017)$ & $(.026)$ & $(.015)$ & $(.010)$ & $(.019)$ & $(.016)$ \\
\hline \multirow[t]{2}{*}{ Female } & & $-.168^{* * *}$ & $-.308^{* * *}$ & $-.314^{* * *}$ & -.022 & $-.137^{* * *}$ & $-.216^{* * *}$ & $-.282^{* * *}$ & $-.111^{* * *}$ & $-.109^{* * *}$ & $-.107^{* * *}$ & $-.228^{* * *}$ \\
\hline & & $(.026)$ & $(.026)$ & $(.028)$ & (.022) & $(.014)$ & $(.028)$ & $(.027)$ & $(.025)$ & $(.014)$ & $(.026)$ & (.032) \\
\hline $\mathrm{R}^{2}$ & & .278 & .381 & .438 & .337 & .297 & .410 & .323 & .392 & .252 & .301 & .420 \\
\hline Observations & & 1018 & 1322 & 1441 & 1013 & 1519 & 816 & 1198 & 1190 & 1316 & 1671 & 983 \\
\hline
\end{tabular}

Notes: Least squares regressions weighted by sampling weights. Dependent variable: log gross hourly wage. Sample: full-time employees aged 35-54 (Canada includes part-time employees). Numeracy score standardized to std. dev. 1 within each country. Experience ${ }^{2}$ divided by 1000. Pooled specification includes country fixed effects and gives same weight to each country; $\mathrm{R}^{2}$ refers to within-country $\mathrm{R}^{2}$. Robust standard errors in parentheses. Data source: PIAAC. 
Table 5: Returns to Skills for Alternative Skill Measures: Numeracy, Literacy, and Problem Solving

\begin{tabular}{|c|c|c|c|c|c|c|c|}
\hline \multirow{3}{*}{ Numeracy } & $(1)$ & $(2)$ & $(3)$ & $(4)$ & $(5)$ & $(6)$ & $(7)$ \\
\hline & $.178^{* * *}$ & & & $.120^{* * *}$ & $.121^{* * *}$ & $.078^{* * *}$ & \\
\hline & $(.003)$ & & & $(.005)$ & $(.005)$ & $(.007)$ & \\
\hline Literacy & & $.171^{* * *}$ & & $.068^{* * *}$ & & $.076^{* * *}$ & \\
\hline & & $(.003)$ & & $(.005)$ & & $(.007)$ & \\
\hline Problem solving & & & $.143^{* * *}$ & & $.062^{* * *}$ & $.037^{* * *}$ & \\
\hline & & & $(.003)$ & & $(.005)$ & $(.005)$ & \\
\hline Numeracy (international standardization) & & & & & & & $\begin{array}{l}.183^{* * *} \\
(.003)\end{array}$ \\
\hline $\mathrm{R}^{2}$ (within country) & .209 & .196 & .173 & .215 & .199 & .205 & .208 \\
\hline Countries & 22 & 22 & 18 & 22 & 18 & 18 & 22 \\
\hline Observations & 34447 & 34447 & 24475 & 34447 & 24475 & 24475 & 34447 \\
\hline
\end{tabular}

Notes: Least squares regressions pooling all countries with country fixed effects, weighted by sampling weights (giving same weight to each country). Dependent variable: log gross hourly wage. Sample: full-time employees aged 35-54 (Canada includes part-time employees). All regressions control for gender, a quadratic polynomial in actual work experience, and country fixed effects. Test scores standardized to std. dev. 1 within each country, except for column (7) where numeracy score is standardized to std. dev. 1 in the entire international sample. All models with problem solving do not include Cyprus, France, Italy, and Spain, where problem-solving skills were not tested, as well as individuals who opted out of the problem-solving test. Robust standard errors in parentheses. Data source: PIAAC. 
Table 6: What Accounts for Differences in Returns to Skills across Countries?

\begin{tabular}{|c|c|c|c|c|c|c|c|c|}
\hline & $(1)$ & $(2)$ & $(3)$ & $(4)$ & $(5)$ & $(6)$ & $(7)$ & $(8)$ \\
\hline \multirow[t]{2}{*}{ Numeracy } & $.180^{* * *}$ & $.186^{* * *}$ & $.181^{* * *}$ & $.181^{* * *}$ & $.174^{* * *}$ & $.184^{* * *}$ & $.184^{* * *}$ & $.089^{* * *}$ \\
\hline & $(.007)$ & $(.008)$ & $(.008)$ & $(.009)$ & $(.008)$ & $(.005)$ & $(.005)$ & $(.006)$ \\
\hline \multirow[t]{2}{*}{$\times$ Union density } & $-.139^{* * *}$ & & & & & $-.150^{* * *}$ & $-.129^{* *}$ & $-.119^{* *}$ \\
\hline & $(.026)$ & & & & & $(.042)$ & $(.046)$ & $(.043)$ \\
\hline \multirow[t]{2}{*}{$\times$ Empl. protection } & & $-.040^{* *}$ & & & & $-.032^{* * *}$ & $-.032^{* * *}$ & $-.034^{* * *}$ \\
\hline & & $(.016)$ & & & & $(.011)$ & $(.011)$ & (.009) \\
\hline \multirow[t]{2}{*}{$\times$ Minimum wage } & & & $.039^{* *}$ & & & -.023 & -.018 & -.020 \\
\hline & & & $(.018)$ & & & $(.020)$ & $(.020)$ & $(.019)$ \\
\hline \multirow[t]{2}{*}{$\times \mathrm{PM}$ regulation } & & & & -.030 & & -.033 & -.024 & -.011 \\
\hline & & & & $(.031)$ & & $(.021)$ & $(.020)$ & $(.020)$ \\
\hline \multirow[t]{2}{*}{$\times$ Public sector } & & & & & $-.278^{* *}$ & -.117 & $-.160^{*}$ & $-.171^{* *}$ \\
\hline & & & & & $(.110)$ & $(.093)$ & $(.084)$ & $(.067)$ \\
\hline \multirow[t]{2}{*}{$\times$ Skill inequality } & & & & & & & .000 & -.000 \\
\hline & & & & & & & $(.001)$ & $(.001)$ \\
\hline \multirow[t]{2}{*}{$\times$ Skill mean } & & & & & & & -.000 & -.000 \\
\hline & & & & & & & $(.001)$ & $(.000)$ \\
\hline Country fixed effects & yes & yes & yes & yes & yes & yes & yes & yes \\
\hline $\begin{array}{l}\text { Occupation } \times \text { industry } \\
\text { fixed effects }[185]\end{array}$ & & & & & & & & yes \\
\hline $\mathrm{R}^{2}$ (within country) & .216 & .214 & .210 & .213 & .211 & .218 & .218 & .408 \\
\hline Countries & 21 & 21 & 22 & 21 & 22 & 21 & 21 & 21 \\
\hline Observations & 33509 & 33509 & 34447 & 33509 & 34447 & 33509 & 33509 & 32798 \\
\hline
\end{tabular}

Notes: Least squares regressions pooling all countries with country fixed effects, weighted by sampling weights (giving same weight to each country) Dependent variable: log gross hourly wage. Sample: full-time employees aged 35-54 (Canada includes part-time employees). All regressions control for gender, a quadratic polynomial in actual work experience, and country fixed effects. All variables are de-meaned. Union density: share of wage and salary earners who are trade union members. Empl. protection: employment protection legislation (EPL), composite indicator measuring strictness of employment protection for individual and collective dismissals. Minimum wage: binary variable indicating whether country has a statutory minimum wage. PM regulation: composite indicator measuring product-market regulation (PMR). Public sector: share of workers employed in the public sector. Skill inequality: numeracy score differential between 90th and 10th percentile of numeracy skill distribution. Skill mean: mean numeracy score of the country. Number in square brackets reports the number of occupation $\times$ industry fixed effects. Numeracy score standardized to std. dev. 1 within each country. Due to missing data, Cyprus is only included in columns (3) and (5). Robust standard errors (adjusted for clustering at country level) in parentheses. Data sources: PIAAC, OECD. 